\title{
Graphene oxide nanofilm and chicken embryo extract decrease the invasiveness of HepG2 liver cancer cells
}

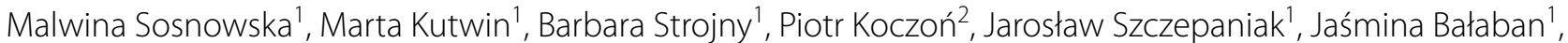 \\ Karolina Daniluk', Sławomir Jaworski ${ }^{1}$, André Chwalibog ${ }^{3}$, Wiesław Bielawski ${ }^{4}$ and Ewa Sawosz ${ }^{1 *}$ (D)
}

\author{
*Correspondence: \\ ewa_sawosz_ \\ chwalibog@sggw.edu.pl \\ ${ }^{1}$ Department \\ of Nanobiotechnology \\ and Experimental Ecology, \\ Institute of Biology, Warsaw \\ University of Life Sciences, \\ Warsaw, Poland \\ Full list of author information \\ is available at the end of the \\ article
}

\begin{abstract}
Background: The extracellular matrix (ECM) is a mosaic of various structural and functional proteins that cooperate with the cell, regulate adhesion, and consequently manage its further fate. Liver destruction is accompanied by a disruption of the physicochemical properties of the ECM which deregulates the cell-ECM interaction and can lead to uncontrolled proliferation and neoplastic transformation of cells. Therefore, it can be assumed that ECM modification and restoration of its characteristics for healthy tissue may counteract uncontrolled cell proliferation. The purpose of the presented research model was to optimise the physical characteristics of ECM by introducing a graphene oxide plane/nanofilm (nfGO) and enriching the cell environment with potentially missing proteins by adding a functional protein cocktail (chicken embryo liver extract) and determine the impact of these factors on cell-ECM cooperation and its consequences on adhesion, proliferation, and cell phase, which are factors of the invasiveness of cancer cells.
\end{abstract}

Results: Experiments were performed with non-cancer HS-5 cells and liver cancer cells HepG2 and C3A. The cells were divided into four groups: (1) control, (2) cultured on nfGO, (3) cultured with the addition of chicken embryo liver extract (CELE) and (4) cultured on the $\mathrm{nfGO}$ with the addition of CELE. CELE contained 1735 proteins; the top 57 of these proteins have been presented. The use of nfGO as well as CELE and $\mathrm{nfGO}+\mathrm{CELE}$ reduced the proliferation of HepG2 cancer cells to the greatest extent; this is in contrast to non-cancer cells and also to C3A cancer cells. Furthermore, the combined use of the CELE protein cocktail and GO substrate effectively resulted in a decrease in the population of HepG2 cells in the G0/G1 phase and an increase of the population in G2/M. Molecular analysis of HepG2 cancer cells also showed an increase in the expression of genes responsible for adhesion such as focal adhesion kinase (fak), e-cadherin, and $n$-cadherin and a decrease in $\beta$-catenin, which is considered a proto-oncogene.

Conclusions: Studies have shown that both the GO surface structure on which the cells are grown as well as the presence of a multi-component natural cocktail of regulatory proteins, can modify the expression of integrins, increase adhesion and, as a consequence, proliferation and the cell cycle-entering the resting phase. For the included in the article's Creative Commons licence and your intended use is not permitted by statutory regulation or exceeds the permitted use, you will need to obtain permission directly from the copyright holder. To view a copy of this licence, visit http://creativecommons.org/ licenses/by/4.0/. The Creative Commons Public Domain Dedication waiver (http://creativecommons.org/publicdomain/zero/1.0/) applies to the data made available in this article, unless otherwise stated in a credit line to the data. 
first time, it has been documented that hepatic cancer cells of the HepG2 line under the influence of stimuli derived from mimic ECM (graphene oxide) in interaction with a unique protein complex derived from chicken liver embryo decreased of the invasiveness of cancer cells.

Keywords: Adhesion, Cell cycle, Embryo liver extract, Extracellular matrix, Graphene oxide nanofilm, Liver cancer, Proliferation

\section{Background}

Hepatocellular carcinoma (HCC) is aggressive, fast growing, and the second cause of cancer death in the world. The key reason for the development of this cancer is liver fibrosis and cirrhosis as a consequence of chronic liver injury (Baglieri et al. 2019) caused by inflammation induced through, inter alia, virus infections (HCV and HBV) (Hernandez-Gea et al. 2013). The inflammatory process is coupled with deepening degradation of the extracellular matrix (ECM). It is also known that from the processes occurring in the cell, its behaviour and fate depend decisively on its environment and above all on the ECM. Disrupted ECM may cause neoplastic transformation of cells, tumour progression, and metastasis (Lu et al. 2012). On the other hand, in the inflammatory process, tumour-associated cells possess impaired secretion of matrix proteins, which leads to overproduction and reorganisation of ECM components. Collagen fibres become thin and branched, and, as a consequence, increase ECM stiffness in fibrotic tissue (Hernandez-Gea et al. 2013; Iredale et al. 2013; Carloni et al. 2014; Klaas et al. 2016). The level of ECM stiffness affects cell proliferation and determines migration, adhesion, and, consequently, the phenotype of the cell. What's more, different tissues have ECM stiffness precisely characteristic and optimal for their proper development (Saneyasu et al. 2016). Paradoxically, ECM degradation can lead to cancer cell transformation, and the resulting cancer cells stimulate the ECM reorganisation (stiffening) process creating a kind of feedback (Iwasaki et al. 2016). Inhibiting this feedback is the key to stopping and possibly treating cancer.

ECM is the physical support for cells recognised by their receptors-integrins. Integrins sense ECM stiffness and transfer signals towards focal adhesion kinase (FAK), cytoskeleton and nucleus (Carloni et al. 2014). Thus, mechanical signals from the cell environment regulate the expression of genes, including genes involved in cell metabolism and in ECM degradation and synthesis (Humphrey et al. 2014). Cancer cells have a reprogrammed metabolism to affect lactic acid synthesis from pyruvate under aerobic conditions (DeBerardinis and Chandel 2016). Acidification of the cell environment ensures activation of ECM remodelling enzymes, which leads to pathology in stiffness, fibre density, and roughness of ECM (Han et al. 2013). Impaired signal transduction to cells promotes relaxation of cell-cell connections. Thus, cooperation between ECM and cancer cells contributes to irreversible liver fibrosis-cirrhosis (Kim et al. 2019).

ECM comprises over 300 proteins, 200 glycoproteins, and 30 proteoglycans that create an extremely complicated and dynamic structure (Humphrey et al. 2014). Loss of several components from the functional and structural protein pool may disrupt their synergistic or antagonistic activity and zonal distribution of ECM components. For example, $\mathrm{HCC}$ is associated with a decrease in the amount of elastic fibres, microfibrils (tenascin), proteoglycans 4, and FACIT collagens (Col14A, Col16A). Furthermore, removal of the 
basement membrane, containing laminins and collagen type 4, facilitates the transition to vessels and invasion (Walker et al. 2018; Baiocchini et al. 2016).

The key strategy for creating artificial ECM is by reconstruction of the physicochemical and mechanical properties of healthy tissue. Carbon allotropes, especially graphene oxide (GO), seems to be promising nanomaterial for the creation of biomimic ECM. The biocompatibility and unique characteristics of GO, in particular flexibility, stability, nano-dimensions, suggest using it as a basic structure of artificial ECM, source of mechano-signalling. Mechanical signalling, derived from a graphene oxide nanofilm, determines the affinity and adhesion of cells (Chaudhuri et al. 2016; Di Crescenzo et al. 2019). We also showed in our research that the GO nanofilm was a source of mechanotransduction modulation for muscle cells (Bałaban et al. 2020). However, stopping feedback also requires the supply of a wide spectrum of ECM proteins, whose production in the process of carcinogenesis has been inhibited or impaired (Lim et al. 2002). Thus, the supply of the main structural missing proteins, such as proteoglycans, elastin, fibrillin-2, collagens, fibulin-3, tenascin, laminin, can inhibit carcinogenesis. It seems that also the missing functional proteins, involved in maintaining the epithelial integrity, assembly of collagen fibres and enzymes involved in detoxification and antioxidation, should be delivered to cancer cells (Klaas et al. 2016; Lim et al.2002).

It seems that a natural mixture of proteins derived from an embryonic liver extract of another species should be a unique source of non-specific factors with multiple functions. Chicken embryo extract, as a source of proteins of a functional and structural nature, is used as an additive to the medium in cell culture in vitro, as well as in regenerative medicine (Essid et al. 2018; Chehelcheraghi et al. 2015). Moreover, chicken embryo extract, which is a cocktail of growth factors prevents uncontrolled proliferation of tumour cells by supplementation with missing ECM biomolecules and expression of regulating suppressor genes (Mu et al. 2014).

In the presented research, for the first time, we wanted to show that, a combination of two signals, mechanotransduction from a ECM-mimicking graphene surface and a molecular signal from the protein cocktail, could inhibit tumour cell-ECM feedback, restore proper cell contact with the environment, inhibit proliferation, and increase the population of cells in the G2/M phase of the cycle.

The objective of this preliminary and model study was to evaluate whether GO nanofilm (nfGO), as a biomimic ECM equivalent, and chicken embryo liver extract (CELE), as a source of essential and missing proteins in tumour tissue, reduce activity characteristic of liver cancer cells and restore the properties of normal cells, particularly in terms of adhesion, proliferation and cell cycle.

\section{Results}

\section{Characterisation of GO}

\section{Characterisation of $G O$ flakes}

GO, observed with TEM, created single-layered, slightly wrinkled flakes that ranged from $100 \mathrm{~nm}$ to $2.9 \mu \mathrm{m}$ in size (Fig. 1a). GO suspended in ultrapure water at a concentration of $50 \mathrm{mg} / \mathrm{L}$ showed high stability and no tendency for agglomeration. The zeta potential of the $\mathrm{GO}$ was $-27.5 \mathrm{mV}$. 

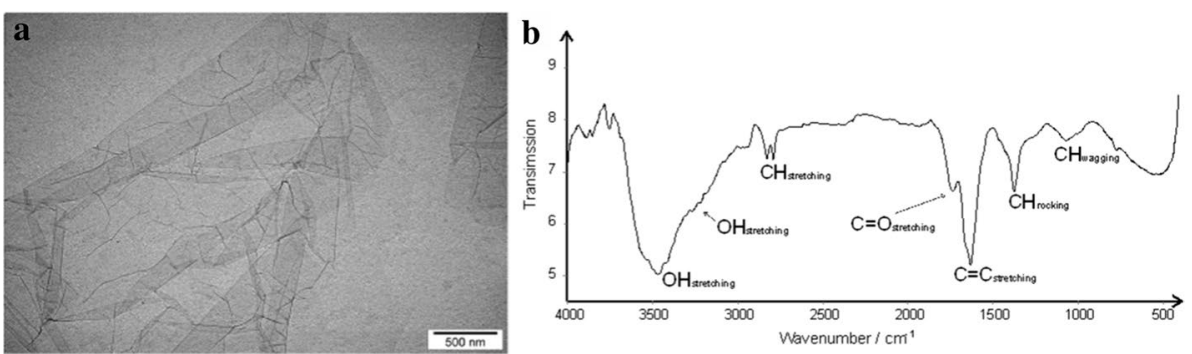

Fig. 1 Characterisation of graphene oxide flakes. a Transmission electron microscopy image of graphene oxide. Scale bar: $500 \mathrm{~nm}$. b Fourier transform infrared spectrum of graphene oxide in the middle region $\left(4000-500 \mathrm{~cm}^{-1}\right)$

Chemical groups present on GO were identified by the Fourier transform infrared (FTIR) method (Fig. 1b). To the left characteristic intense, broad band at $3457 \mathrm{~cm}^{-1}$ is present. This band corresponds to $\mathrm{O}-\mathrm{H}$ stretching that is assigned to alcohol-like groups connected directly to graphene surface through oxygen atom. Some of the $\mathrm{OH}$ groups interact with each other by hydrogen bonds that is reflected by the band at $3217 \mathrm{~cm}^{-1}$. This band, however, can also be assigned to stretching of $\mathrm{OH}$ groups present in carboxylic group (COOH). Further, characteristic bands at $2817 \mathrm{~cm}^{-1}$ and $2779 \mathrm{~cm}^{-1}$ are present. Both are generated by stretching of $\mathrm{C}-\mathrm{H}$ from carbon chain. In bands that vibrations generate those bands carbons are $\mathrm{sp}^{3}$ hybridised. Next, the $\mathrm{C}=\mathrm{O}$ stretching located at $1728 \mathrm{~cm}^{-1}$ confirms the presence of at least some oxygen attached to carbon. In this case, both carbon and oxygen atoms are $\mathrm{sp}^{2}$ hybridised. The band at $1728 \mathrm{~cm}^{-1}$ can be assigned to the carboxylic group (carboxy bond) or carbonyl group. Although usually bands generated by $\mathrm{C}=\mathrm{O}$ stretching from carboxylic group, containing carboxylic acids (propanoic, butanoic or benzoic acids), are located at higher wavenumbers, e.g., $1740-1760 \mathrm{~cm}^{-1}$ (Thygesen et al. 2003), direct bonding of carboxylic group to graphene surface in studied sample changed the $\mathrm{C}=\mathrm{O}$ vibrations of carboxylic group to lower wavenumbers, i.e. $1728 \mathrm{~cm}^{-1}$. However, it cannot be excluded that this band is generated by the carbonyl group attached directly to one of carbons forming graphene surface. Bands generated by aromatic ring carbon-carbon double bands were present at $1621 \mathrm{~cm}^{-1}$ in the GO spectra (Thygesen et al. 2003). This location corresponds to the $\mathrm{sp}^{2}$ character of GO (Kurantowicz et al. 2017). Graphene spectrum also contained two characteristic bands, i.e. $\mathrm{C}-\mathrm{H}$ rocking and wagging located at lower wavenumbers, i.e. $1367 \mathrm{~cm}^{-1}$ and $1061 \mathrm{~cm}^{-1}$. The presence of only seven bands in the spectrum of the GO material confirms its simple composition of only three atoms (carbon, oxygen, and hydrogen).

\section{Characterisation of GO nanofilm}

The characterised GO colloid was used as the only material for nanofilm formation.

GO nanofilm was formed by applying a GO colloid to the bottom of a plastic cell culture plate and drying it. The topography of the surface of the plastic culture plate vs the nfGO-coated plate was determined by atomic force microscopy (AFM) (Fig. 2a, b). It can be seen that the morphology differed significantly between plastic and plastic coated with GO surfaces. The average roughness of the uncoated surface was $\mathrm{Ra}=1.5 \mathrm{~nm}$ 


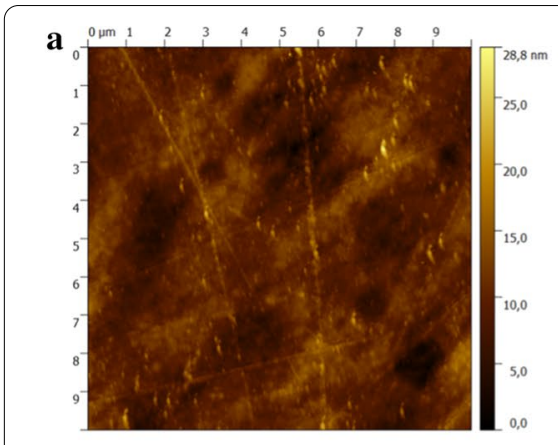

b

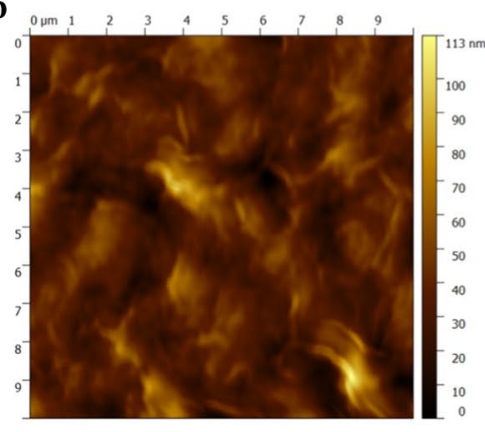

c

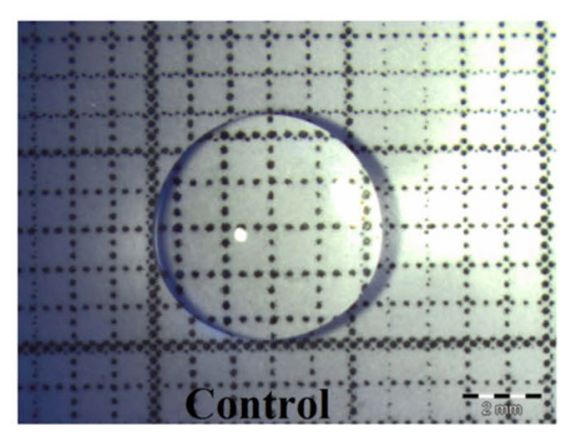

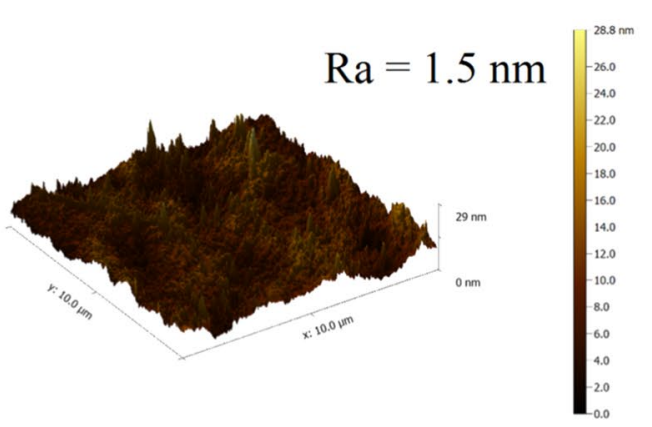
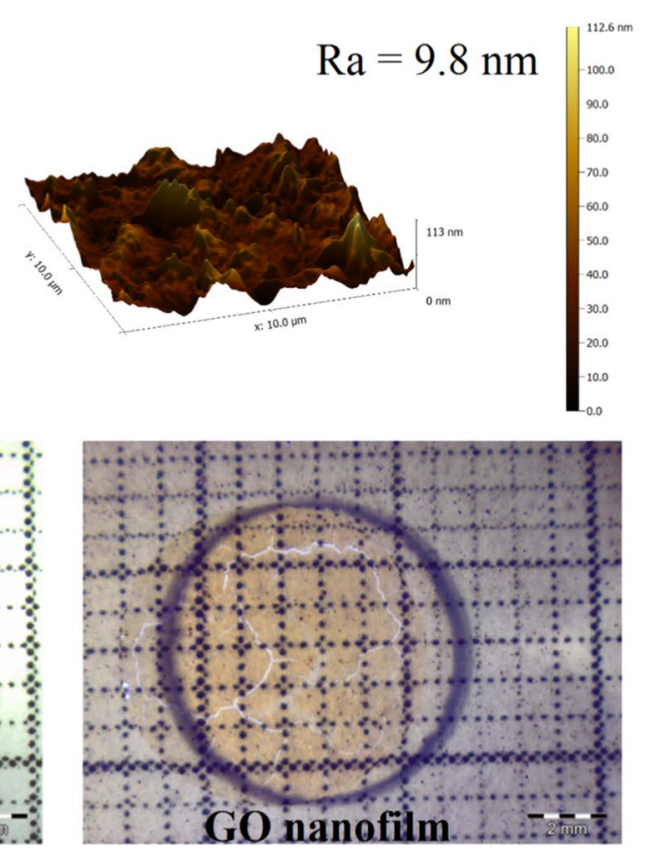

d

Water contact surface

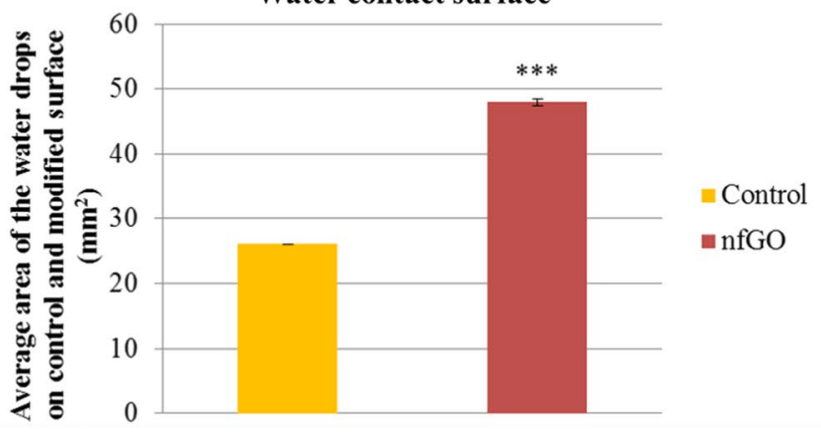

Fig. 2 Characterisation of graphene oxide nanofilm. Topographical image of the uncoated (a scale bar: $10 \mu \mathrm{m} \times 10 \mu \mathrm{m} \times 29 \mathrm{~nm}$ ) and graphene oxide-coated plate (b scale bar: $10 \mu \mathrm{m} \times 10 \mu \mathrm{m} \times 113 \mathrm{~nm}$ ). Left side: face surface. Right side: three-dimensional atomic force microscopy image. Ra: roughness average. c Visualisation of the hydrophilicity properties of graphene oxide nanofilm in relation to the plastic plate surface. Left side: water contact surface on Petri dish. Right side: water contact surface on Petri dish coated with GO nanofilm. Scale bar $2 \mathrm{~mm}$. d Comparison of water drop area on clean polystyrene surface and polystyrene surface coated with nfGO using Image J 
(Fig. 2a) and the roughness of the coated surface was $\mathrm{Ra}=9.8 \mathrm{~nm}$ (Fig. 2b). Moreover, the maximum height of the roughness of the $\mathrm{nfGO}$-coated plate was $67.7 \mathrm{~nm}$. Some dense, transverse inequalities of GO were seen, corresponding to flakes arrangement. This structure was created through self-organisation and generated a structurally varied surface, formed by GO flakes. The average roughness of the surface increased about six times and its greatest height was less than $100 \mathrm{~nm}$, which entitles it to be called a nanofilm.

The hydrophilicity of the surface covered with nfGO vs the polystyrene surface was measured. Generally, the contact surface of a water droplet on the nfGO was higher than on the uncoated plate (Fig. 2c). As shown in Fig. 2d, the area of the water droplet was increased about two times on the modified surface compared to the control; thus, the hydrophilicity of the surface increased after coating with GO.

\section{Characterisation of liver extract}

Chemical groups present on CELE and nfGO + CELE were identified by the FTIR method (Additional file 1: Figure S1). Visual inspection of spectra evidenced that the extract chemically binds to GO. Bands characteristic for extract, e.g., very intense and wide $\mathrm{OH}$ band originated from hydrogen bonds are present on the spectrum of nfGO + CELE. All specific bands from GO are overwhelmed by CELE bands, expect very intense $\mathrm{C}=\mathrm{C}$ band at $1621 \mathrm{~cm}^{-1}$. Additionally, the band generated by triple carbon-carbon bonds present in CELE is also present in nfGO + CELE spectrum.

1735 proteins were identified in the CELE by mass spectrometry analysis. The exact formulation of these proteins has been registered in PRoteomics IDentifications Database (2020). The functions and scope of activity of the identified proteins were determined on the basis of the UniProt database, and on this basis 57 key proteins were selected that could be involved in adhesion, ECM organisation, migration, epithelialmesenchymal transition (EMT), proliferation, cell cycle, and apoptosis of cancer cells of the liver (Table 1).

\section{Influence of nfGO and CELE on cell morphology}

The morphological picture of non-tumour HS-5 cells after $48 \mathrm{~h}$ of incubation on GO nanofilm, with the addition of CELE and using both factors, did not indicate pathological changes, however, some differences could be found (Fig. 3). Cells growing on the nfGO were extended and possessed large cell bodies, long protrusions, and distinct lamellipodia. Cell clusters and high cell-cell adhesion were observed on the nfGO (Fig. 3b). The CELE induced severe morphological changes in HS-5 cells, such as elongation of filopodia, reduction of cell bodies (shrunken forms), and formation of small clusters (pieces of extract) (Fig. 3c). In the nfGO + CELE group, the HS-5 cell size was reduced and tendency of cells to form clusters was observed (Fig. 3d). The morphometric analysis confirmed the increase of the cell area on the nfGO and the decrease of the cell surface in the CELE and nfGO + CELE groups. The number of cells detected by ImageJ software was reduced due to cell clusters formation in all groups (Table 2).

HepG2 and C3A liver tumour cells form natural clusters as observed in the experiment with the control groups (Figs. 4a, 5a). After $48 \mathrm{~h}$ of culture, HepG2 cancer cells were also not pathologically altered due to surface modification with nfGO and CELE 
Table 1 The top 57 proteins from the chicken liver extract divided into functional activities according to UniProt database, including the name of the gene and the molecular mass of the protein $(\mathrm{kDa})$

\begin{tabular}{|c|c|c|c|}
\hline No. & Gene name & Protein name & Molecular mass (kDa) \\
\hline \multicolumn{4}{|c|}{ Adhesion } \\
\hline 1 & TJP2 & Tight junction protein ZO-2 & 130.7 \\
\hline 2 & LARP1 & La-related protein 1 & 118.6 \\
\hline 3 & $\mathrm{CDH} 1$ & Cadherin-1 & 97.8 \\
\hline 4 & CD2AP & CD2-associated protein & 71.2 \\
\hline 5 & $\begin{array}{l}\operatorname{tr|A0A1D5PRE3|A0A1D5PRE3~} \\
\text { CHICK }\end{array}$ & $\mathrm{N}$-myc downstream regulated & 39.0 \\
\hline 6 & EPCAM & Epithelial cell adhesion molecule & 34.4 \\
\hline 7 & MTDH & Metadherin & 14.2 \\
\hline 8 & BSG & Basigin & Few isoforms \\
\hline \multicolumn{4}{|c|}{ ECM organisation } \\
\hline 9 & LAMA1 & Laminin subunit alpha-1 & 339.1 \\
\hline 10 & COL12A1 & Collagen alpha-1(XII) chain & 333.5 \\
\hline 11 & FN1 & Fibronectin & 273.2 \\
\hline 12 & COL5A1 & Collagen alpha-1(V) chain & 184.2 \\
\hline 13 & LAMC1 & Laminin subunit gamma-1 & 176.5 \\
\hline 14 & PEPD & Xaa-Pro dipeptidase & 55.1 \\
\hline 15 & VTN & Vitronectin & 51.7 \\
\hline 16 & PRDX4 & Peroxiredoxin-4 & 29.6 \\
\hline \multicolumn{4}{|c|}{ Migration and EMT } \\
\hline 17 & PTPN23 & $\begin{array}{l}\text { Tyrosine-protein phosphatase non-receptor type } \\
23\end{array}$ & 179.0 \\
\hline 18 & FAM98A & Protein FAM98A & 58.6 \\
\hline 19 & TWF1 & Twinfilin-1 & 55.2 \\
\hline 20 & MGLL & Monoglyceride lipase & 33.3 \\
\hline 21 & TPM1 & Tropomyosin alpha-1 chain & 32.8 \\
\hline 22 & PBLD & $\begin{array}{l}\text { Phenazine biosynthesis-like domain-containing } \\
\text { protein }\end{array}$ & 32.2 \\
\hline 23 & ADI1 & $\begin{array}{l}\text { 1,2-Dihydroxy-3-keto-5-methylthiopentene } \\
\text { dioxygenase }\end{array}$ & 21.7 \\
\hline \multicolumn{4}{|c|}{ Proliferation and cell cycle } \\
\hline 24 & GOLGA2 & Golgin subfamily A member 2 & 140.1 \\
\hline 25 & MOV10 & Putative helicase MOV-10 & 109.1 \\
\hline 26 & ASMTL & Probable bifunctional dTTP/UTP protein & $\begin{array}{l}\text { pyrophosphatase/ } \\
\text { methyltransferase } \\
70.2\end{array}$ \\
\hline 27 & RPA1 & $\begin{array}{l}\text { Replication protein A 70-kDa DNA-binding } \\
\text { subunit }\end{array}$ & 68.0 \\
\hline 28 & ARID3A & AT-rich interactive domain-containing protein $3 \mathrm{~A}$ & 67.4 \\
\hline 29 & $\mathrm{RIC} 8 \mathrm{~B}$ & Guanine nucleotide exchange factor B & 60.5 \\
\hline 30 & CERS2 & Ceramide synthase 2 & 55.1 \\
\hline 31 & KRT18 & Keratin, type I cytoskeletal 18 & 46.9 \\
\hline 32 & MRPS27 & $28 \mathrm{~S}$ ribosomal protein S27, mitochondrial & 46.7 \\
\hline 33 & TARDBP & DNA-binding protein 43 & 44.6 \\
\hline 34 & CA9 & Carbonic anhydrase 9 & 43.8 \\
\hline 35 & DRG1 & $\begin{array}{l}\text { Developmentally regulated GTP-binding protein } \\
1\end{array}$ & 40.5 \\
\hline 36 & SLC35F6 & Solute carrier family 35 member F6 & 40.2 \\
\hline 37 & AIMP2 & $\begin{array}{l}\text { Aminoacyl tRNA synthase complex-interacting } \\
\text { multifunctional protein } 2\end{array}$ & 34.5 \\
\hline
\end{tabular}


Table 1 (continued)

\begin{tabular}{llll}
\hline No. & Gene name & Protein name & Molecular mass (kDa) \\
\hline 38 & FBXO6 & F-box only protein 6 & 30.7 \\
39 & HPGD & 15-Hydroxyprostaglandin dehydrogenase & 29.0 \\
40 & PSMD9 & [NAD(+)] & \\
41 & NIT2 & 26S proteasome non-ATPase regulatory subunit 9 & 22.7 \\
42 & DYNLL1 & Nitrilase NIT2 & 22.1 \\
Apoptosis & Dynein light chain & 10.3 \\
43 & HTT & & \\
44 & PARP1 & Huntingtin & 344.0 \\
45 & DNMT3A & Poly [ADP-ribose] polymerase & 113.1 \\
46 & ATAD3A & DNA (cytosine-5)-methyltransferase 3A & 99.0 \\
47 & SGPL1 & ATPase family AAA domain-containing protein 3A & 67.2 \\
48 & CTSC & Sphingosine-1-phosphate lyase 1 & 61.1 \\
49 & FKBP8 & Dipeptidyl peptidase 1 & 59.4 \\
50 & AIFM2 & Peptidylprolyl isomerase & 44.3 \\
51 & APIP & Apoptosis-inducing factor 2 & 40.6 \\
52 & PDCD10 & Methylthioribulose-1-phosphate dehydratase & 26.8 \\
53 & ENDOG & Programmed cell death protein 10 & 24.7 \\
54 & FAM162A & Endonuclease G, mitochondrial & 22.2 \\
55 & HIGD1A & Protein FAM162A & 17.1 \\
56 & DYNLL1 & HIG1 domain family member 1A, mitochondrial & 10.7 \\
57 & NQO1 & Dynein light chain & 10.3 \\
\hline & & NAD(P)H dehydrogenase [quinone] 1 & Few isoforms \\
\hline
\end{tabular}

addition. Moreover, none of the experimental factors significantly changed their morphology (Fig. 4). Although it was observed that the cells were willingly located on the GO coated surface, they appeared to be more shrunken. The CELE additive to the cells increased the total cells' area (Table 2). In the nfGO + CELE group there were more cells not associated in clusters but migrating outside the clusters.

C3A cells also did not undergo pathological changes under the influence of experimental factors (Fig. 5). C3A cells were visible on the GO surface as well as outside it. However, the total area of cells on nfGO was reduced. Under the influence of CELE addition, a number of cells could be seen separated from clusters. In the nfGO + CELE group, a few individual cells migrated outside of the clusters.

The morphology of the cells was also observed using scanning electron microscopy (SEM). Cells were grown on plates, which were only partially covered with nfGO. This enabled cells to be visualised on the GO surface and, above all, on the border of the GO surface and the surface of the plastic dish. The image of the cells after 7 days of culture allowed an assessment of their preferences for their placement on nfGO or outside of nfGO.

HS-5 cells were evenly located both on nfGO and outside nfGO as well as on the plastic/nfGO border. Cell settlement topography did not reflect the plastic/nfGO border line, although cells on nfGO had slightly longer protrusions and were more elongated (Fig. 6).

Liver cancer cells exhibit different culture behaviour, forming characteristic clusters that have been observed with HepG2. Cluster formation was observed both on 


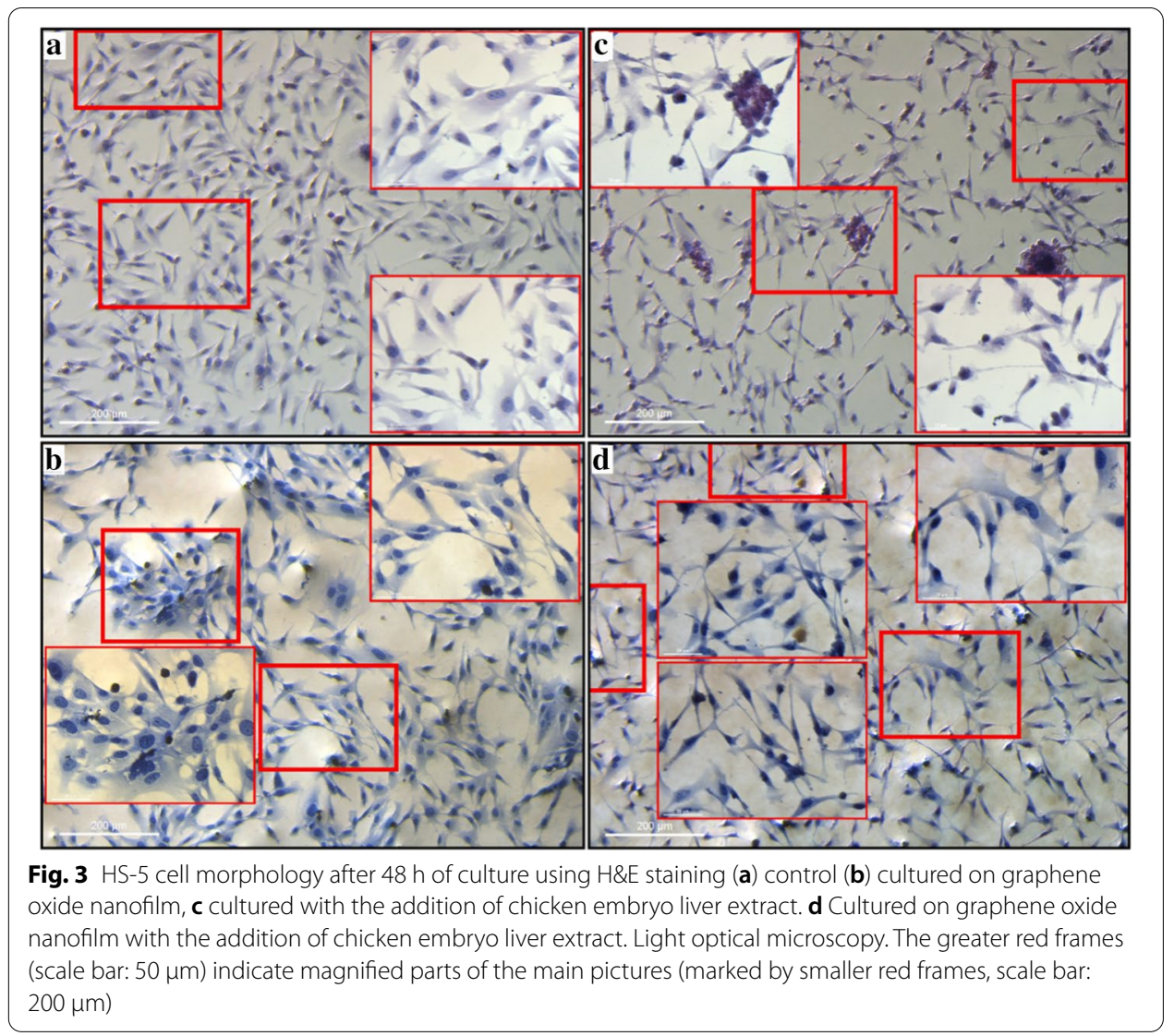

Table 2 Quantitative analysis of morphological images

\begin{tabular}{|c|c|c|c|c|c|c|c|}
\hline Cell line & Group $^{a}$ & $\begin{array}{l}\text { Number } \\
\text { of cells } / \mathrm{mm}^{2}\end{array}$ & SE & $p$-value & $\begin{array}{l}\text { Area covered } \\
\text { by cells (\%) }\end{array}$ & SE & $p$-value \\
\hline \multirow[t]{4}{*}{ HS-5 } & Control & 507 & 26.3 & 0.0139 & 36.4 & 1.42 & $<0.0001$ \\
\hline & nfGO & 434 & & & $44.1^{* *}$ & & \\
\hline & CELE & $402^{\mathrm{a}}$ & & & $31.2^{\mathrm{a}}$ & & \\
\hline & $\mathrm{nfGO}+\mathrm{CELE}$ & $407^{a}$ & & & 33.9 & & \\
\hline \multirow[t]{4}{*}{ HepG2 } & Control & 274 & 34.2 & 0.0112 & 32.7 & 2.98 & 0.0008 \\
\hline & nfGO & 310 & & & 29.9 & & \\
\hline & CELE & 246 & & & $41.8^{\mathrm{a}}$ & & \\
\hline & $\mathrm{nfGO}+\mathrm{CELE}$ & $396^{a}$ & & & $48.9^{* *}$ & & \\
\hline \multirow[t]{4}{*}{ C3A } & Control & 245 & 33.0 & 0.0702 & 35.6 & 2.40 & $<0.0001$ \\
\hline & nfGO & 306 & & & $23.9^{* *}$ & & \\
\hline & CELE & $351^{\mathrm{a}}$ & & & $54.1^{* * *}$ & & \\
\hline & $\mathrm{nfGO}+\mathrm{CELE}$ & 290 & & & 35.5 & & \\
\hline
\end{tabular}

ImageJ software was used to calculate total cells area and number of cells

a nfGO: graphene oxide nanofilm, CELE: chicken embryo liver extract, significant ${ }^{*} p<0.05,{ }^{* *} p<0.01,{ }^{* * *} p<0.001$

the plastic surface of the culture vessel as well as on nfGO and at the plastic/nfGO border. Observation of the image of cells colonising on nfGO showed that the cells formed looser clusters with single cells more visible. The tendencies to create groups 


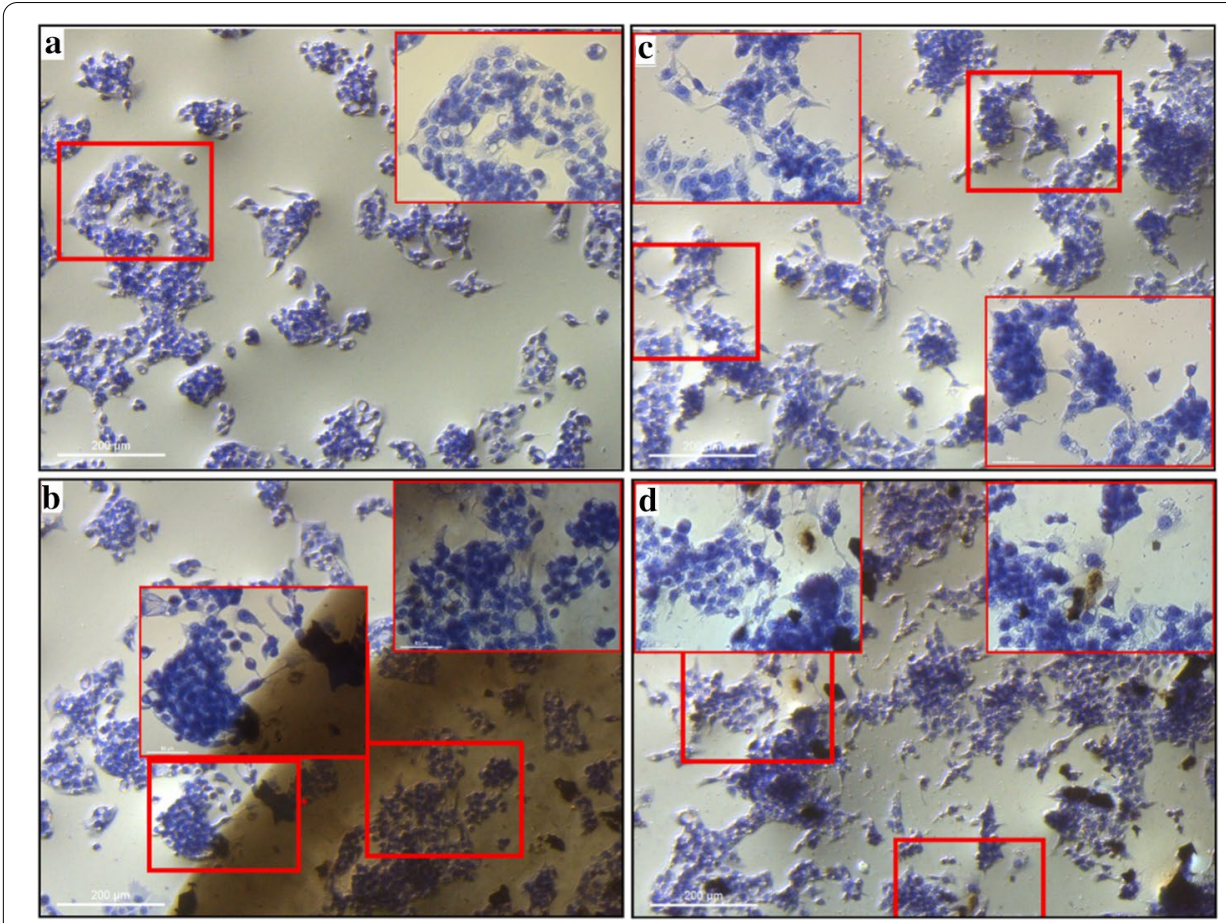

Fig. 4 HepG2 cell morphology after 48 h of culture using H\&E staining (a) control (b) cultured on graphene oxide nanofilm, c cultured with the addition of chicken embryo liver extract, $\mathbf{d}$ cultured on graphene oxide nanofilm with the addition of chicken embryo liver extract. Light optical microscopy. The greater red frames (scale bar: $50 \mu \mathrm{m}$ ) indicate magnified parts of the main pictures (marked by smaller red frames, scale bar: $200 \mu \mathrm{m})$

(clusters) were clearly smaller, and the adherence of individual cells to the GO substrate seemed larger (Fig. 7).

C3A cells, like HepG2, formed clusters, colonising both the graphene surface and the plastic/nfGO border. In the nfGO group, slightly more single cells not bound into clusters were also observed (Fig. 8).

\section{Wound healing assay}

Two-dimensional migration assay was performed without scratching cells, using inserts. Cell migration was assessed after 24,48 and $72 \mathrm{~h}$ of incubation on nfGO, CELE and nfGO + CELE. nfGO reduced the two-dimensional migration of HS-5 cells. Moreover, CELE did not induce statistically significant changes in wound healing. The use of both factors increased the invasion of normal cells, leaving $31 \%$ of free gap (Additional file 1: Figure S2, Table S1).

After 48 and $72 \mathrm{~h}$, the strong inhibition of cancer cell invasion was observed in nfGO and nfGO + CELE groups. Results showed that CELE could enhance HepG2 cells invasion and inhibit C3A cells. Moreover, C3A cells showed a stronger ability to migrate than HepG2 cells (Additional file 1: Figures S3, S4). 


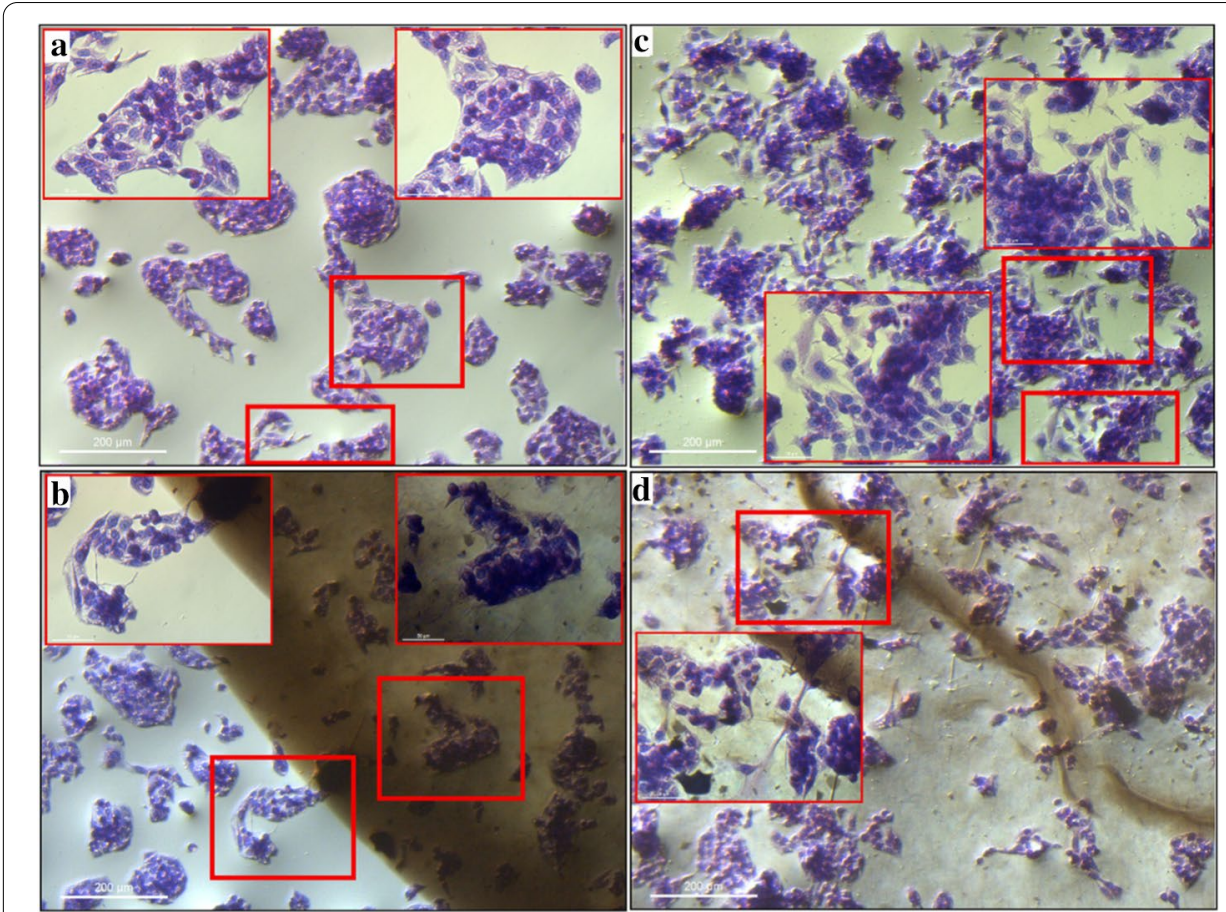

Fig. 5 C3A cell morphology after $48 \mathrm{~h}$ of culture using H\&E staining (a) control (b) cultured on graphene oxide nanofilm, c cultured with the addition of chicken embryo liver extract, $\mathbf{d}$ cultured on graphene oxide nanofilm with the addition of chicken embryo liver extract. Light optical microscopy. The greater red frames (scale bar: $50 \mu \mathrm{m}$ ) indicate magnified parts of the main pictures (marked by smaller red frames, scale bar: $200 \mu \mathrm{m})$

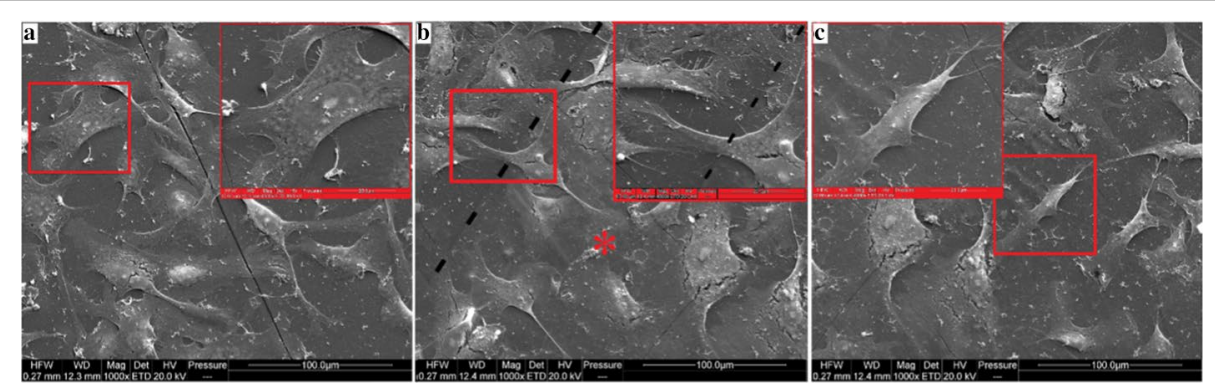

Fig. 6 HS-5 cell morphology by scanning electron microscopy after 7 days of culture. a Cultured on standard polystyrene plate, $\mathbf{b}$ cultured on graphene oxide nanofilm partly covering a standard polystyrene plate (red asterisk), c cultured on graphene oxide nanofilm. Black dotted line indicates the border between the polystyrene and graphene surface. The greater red frames (scale bar: $20 \mu \mathrm{m}$ ) indicate magnified parts of the main pictures (marked by smaller red frames, scale bar: $100 \mu \mathrm{m}$ )

\section{Influence of nfGO and CELE on cell viability}

Cell viability was measured based on conversion MTT (3-(4,5-dimethylthiazol-2-yl)2,5-diphenyltetrazolium bromide) to formazan. All experimental factors were nontoxic for cells (Fig. 9, Additional file 1: Table S2). However, HS-5 cells viability was slightly inhibited in medium with additive CELE. In contrast to normal cells, cancer cells metabolism was enhanced by CELE. 


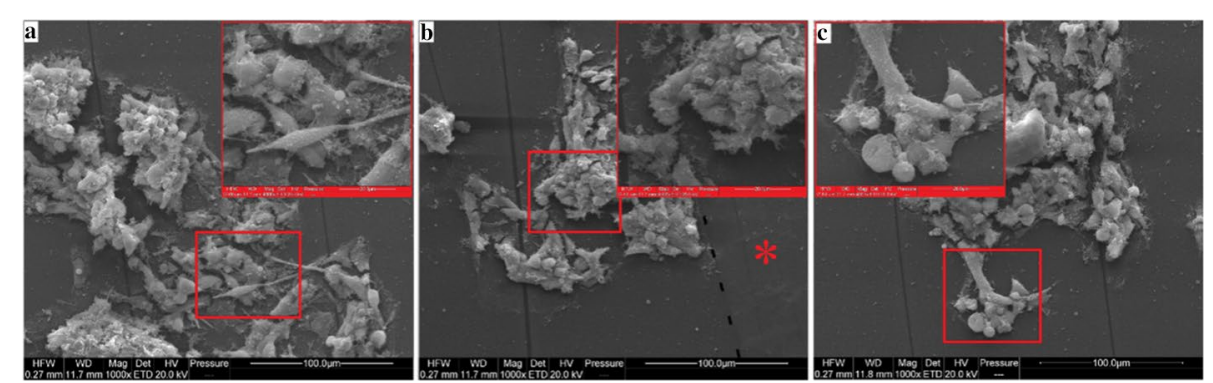

Fig. 7 HepG2 cell morphology after 7 days by scanning electron microscope. a Cultured on standard polystyrene plate, $\mathbf{b}$ cultured on graphene oxide nanofilm partly covering a standard polystyrene plate (red asterisk), c cultured on graphene oxide nanofilm. Black dotted line indicates the border between polystyrene and graphene surface. The greater red frames (scale bar: $20 \mu \mathrm{m}$ ) indicate magnified parts of the main pictures (marked by smaller red frames, scale bar: $100 \mu \mathrm{m}$ )

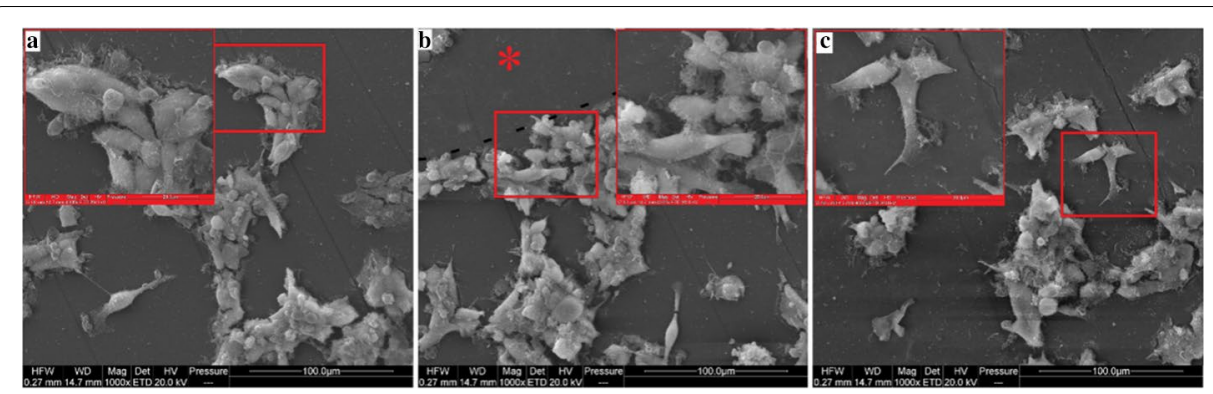

Fig. 8 C3A cell morphology after 7 days of culture by scanning electron microscope. a Cultured on standard polystyrene plate, $\mathbf{b}$ cultured on graphene oxide nanofilm partly covering a standard polystyrene plate (red asterisk), c cultured on graphene oxide nanofilm. Black dotted line indicates the border between polystyrene and graphene surface. The greater red frames (scale bar: $20 \mu \mathrm{m}$ ) indicate magnified parts of the main pictures (marked by smaller red frames, scale bar: $100 \mu \mathrm{m}$ )

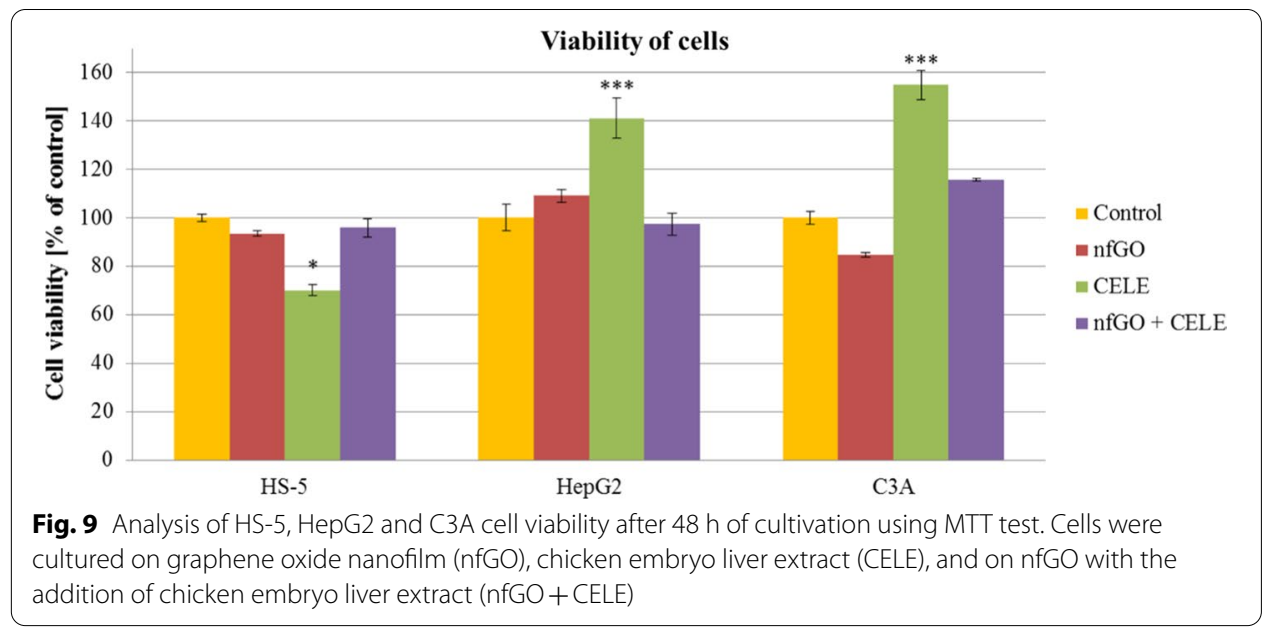

\section{Influence of nfGO and CELE on cell proliferation}

Cell proliferation was measured by using the test based on the measurement of BrdU incorporation during DNA synthesis (Fig. 10, Additional file 1: Table S3). The experimental factors did not affect the proliferation of non-tumour HS-5 cells. In 


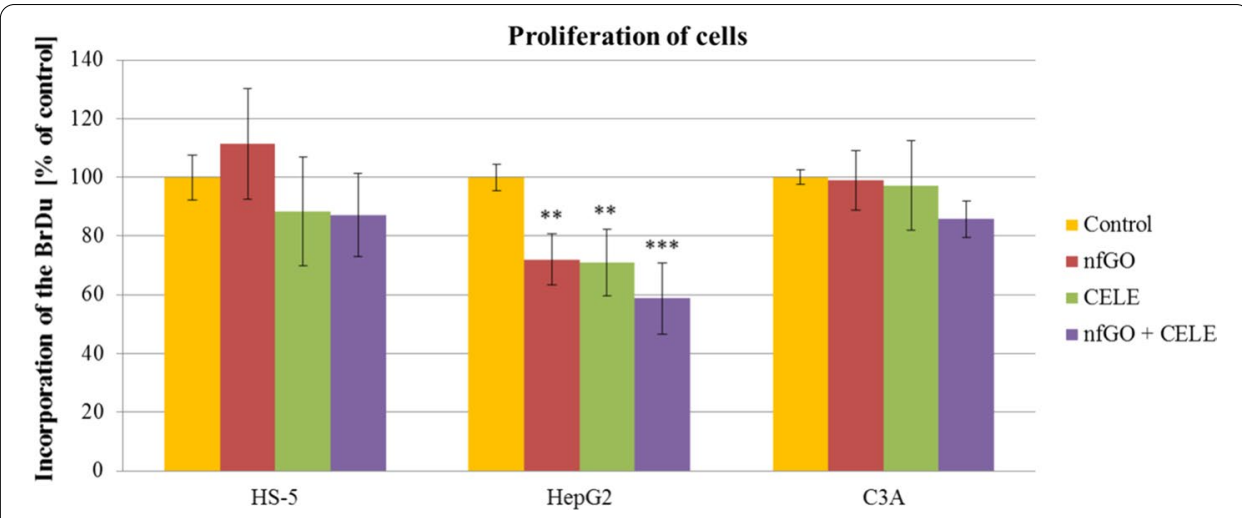

Fig. 10 Analysis of HS-5, HepG2 and C3A cell proliferation after $48 \mathrm{~h}$ of cultivation using BrdU test. Cells were cultured on graphene oxide nanofilm (nfGO), chicken embryo liver extract (CELE), and on graphene oxide nanofilm with the addition of chicken embryo liver extract (nfGO + CELE)

contrast with HS-5 cells, nfGO, CELE, and to the greatest extent the combined factors (nfGO + CELE) reduced the proliferation of HepG2 cells. However, none of the experimental factors significantly influenced the proliferation of C3A cells.

\section{Influence of nfGO and CELE on proliferation-associated gene expression at the mRNA level}

In order to clarify the molecular basis of proliferation under the influence of the signal induced by the GO nanofilm and the addition of CELE, the mRNA expression of the pcna, ki67, and mcm2 genes was studied (Fig. 11).

The cultivation of HS-5 cells on nfGO as well as on nfGO with CELE addition resulted in a decrease in pcna expression, an increase in ki67 expression, and a tendency towards an increase in $m c m 2$ expression. However, the addition of CELE to the medium did not change the expression of the mitotic index markers.

HepG2 tumour cells showed a slightly different response to the factors tested. Surface modification by nfGO was the reason for the increased expression of ki67 and $\mathrm{mcm} 2$. This was in contrast to the CELE, which reduced the expression of all genes ( $p c n a, k i 67$ and $m c m 2$ ). The effect of the GO surface was to reduce the CELE interaction on pcna expression. Moreover, the nfGO eliminated the effects of CELE on ki67, and the combined use of these factors was the cause of overexpression of the ki67 gene. A similar picture was observed in the case of $m c m 2$, where the CELE effect was levelled by the surface treatment.

The influence of experimental factors on C3A cells was smaller. Some overexpression of the ki67 and $m c m 2$ genes was observed under the influence of nfGO as well as the nfGO together with the CELE.

\section{The cell-ECM and cell-cell connections}

\section{Integrin expression profile}

The modification of the culture plate surface by using nfGO increased the expression of $\alpha 1, \alpha 2, \alpha 3, \alpha 5, \alpha 6$, and $\beta 4$ and decreased the expression of $\beta 1$ integrins in non-cancer cells HS-5 (Fig. 12, Additional file 1: Table S4). In turn, the addition of CELE elevated the expression of integrin $\alpha V$ and $\beta 1$ and reduced the $\alpha 2, \alpha 3$, and $\beta 4$ integrin mRNA level. 


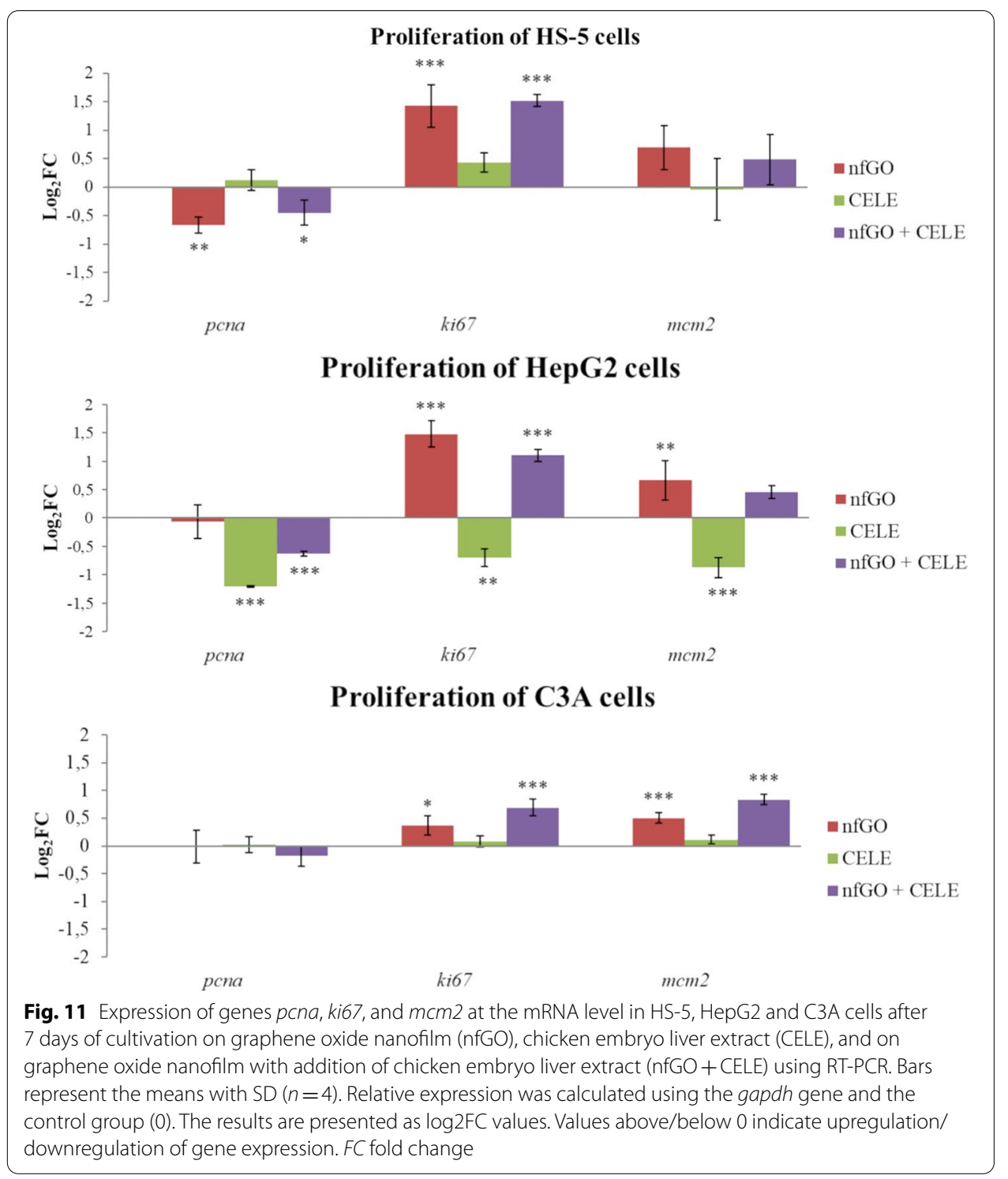

The use of both factors (nfGO + CELE) caused overexpression of $\alpha 1, \alpha 3, \alpha 5$, and especially $\alpha 4, \alpha V$, and $\beta 1$ in HS-5 cells.

Integrin expression in HepG2 cancer cells was completely different. A reduction in the $\alpha 3$ and $\alpha 5$ mRNA level was found, while an increase in $\alpha 1, \alpha 6, \alpha V$, and $\beta 4$ was influenced by the use of graphene surfaces. The opposite effect was observed under the influence of CELE for integrins $\alpha 1, \alpha 5, \alpha 6$, and $\alpha V$. The use of both factors was clearly the cause of integrin overexpression $\alpha 2, \alpha 5, \alpha V$, and $\beta 4$ in HepG2 cells (Additional file 1: Table S5).

A different effect was observed in C3A tumour cells than in HepG2. First of all, no factor influenced downregulation of integrin expression. The surface of the nanofilm induced the integrin expression $\alpha 1, \alpha 2, \alpha 3, \alpha 6, \alpha V, \beta 1$, and $\beta 4$, while CELE induced an increase in $\alpha 1, \alpha 2, \alpha 3, \alpha 6, \alpha V$, and $\beta 1$ integrins (Additional file 1: Table S6). Interestingly, the combined use of both factors (nfGO + CELE) resulted in a decrease in the expression of most integrins compared to their use separately. 


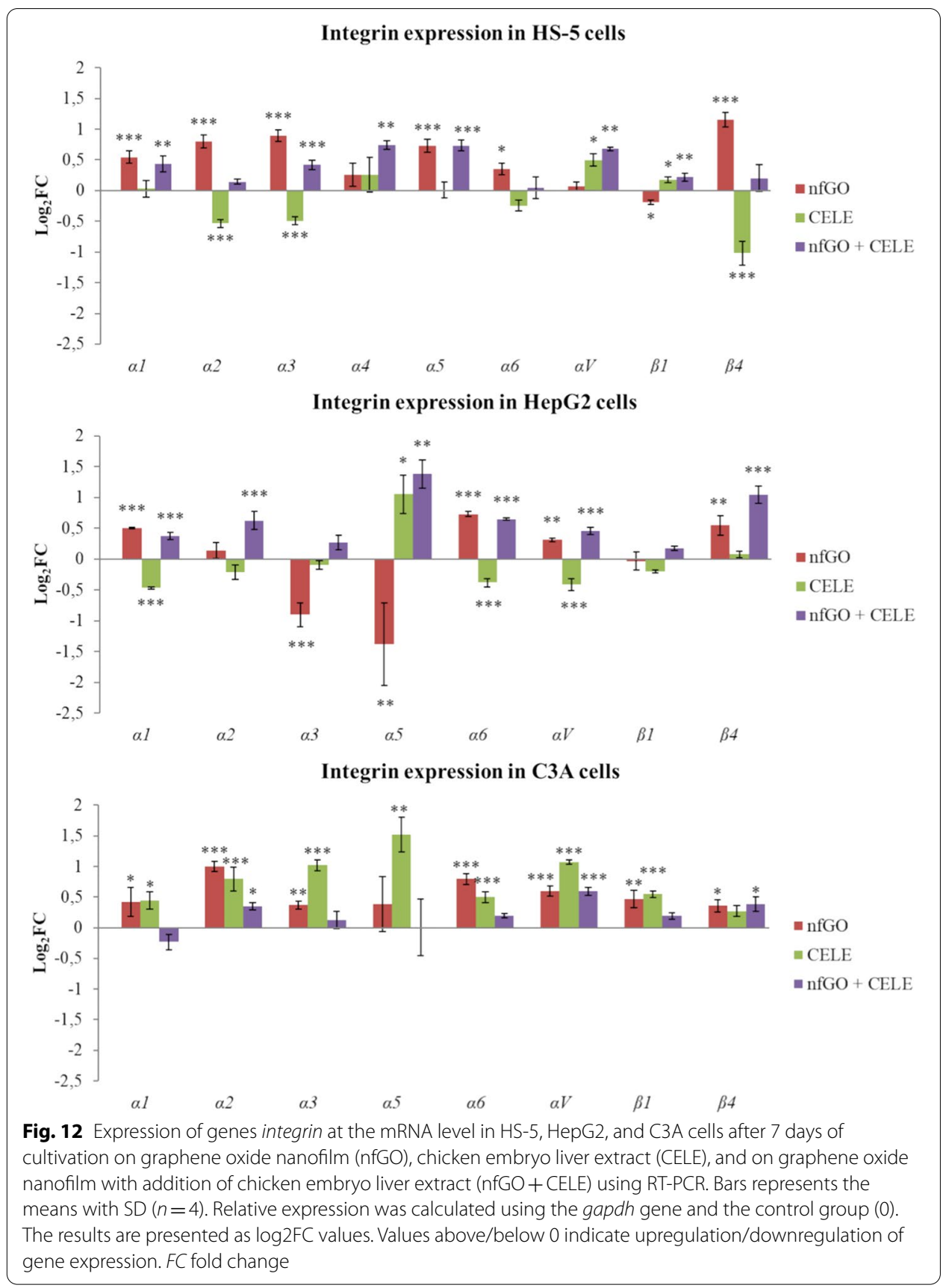

Thus, mutual enhancement of the surface effect and addition of CELE to the culture medium was observed in non-tumour cells for $\alpha 4$ and $\alpha V$ integrins and above all in HepG2 tumour cells for $\alpha 2, \alpha 5, \alpha V$, and $\beta 4$ integrins.

\section{Focal adhesion kinase, cadherins and $\beta$-catenin}

Gene expression for key proteins involved in the integration of mechano- and chemosignalling between ECM-cell and cell-cell, such as fak, e-cadherin, n-cadherin, and $\beta$-catenin is presented in Fig. 12. By analysing gene expression in HS-5 cells, it was found that the surface modification by GO only significantly increased the 
expression of $n$-cadherin, while the CELE did not affect the results. The combined use of nfGO + CELE resulted in significant overexpression of all adhesion markers (Additional file 1: Table S4).

In the HepG2 liver cancer line, the use of nfGO resulted in a significant increase in the expression of genes responsible for cell-ECM adhesion $(f a k)$ as well as cell-cell adhesion (cadherins). Moreover, nfGO decreased the expression of $\beta$-catenin. Unlike other genes, the expression of $\beta$-catenin was also downregulated by CELE. The use of both factors (nfGO + CELE) clearly increased the expression of fak, e-cadherin, and $n$-cadherin and reduced the expression of $\beta$-catenin (Additional file 1: Table S5).

C3A cells cultured on nfGO showed higher expression of fak compared to the control group. Furthermore, we found that the CELE supplementation increased $n$-cadherin expression. Nanofilm GO with additive CELE increased $n$-cadherin and $\beta$-catenin expression of C3A cells (Fig. 13, Additional file 1: Table S6).

\section{Effect on cell cycle}

To investigate whether the mechanical signal from nfGO and a molecular signal from a CELE influence cell cycle, flow cytometric analysis was performed (Fig. 14, Additional file 1: Table S7). HS-5 cells cultured on GO nanofilm as well as cultured with additives of CELE but also treated nfGO + CELE for 7 days showed a decrease in the population of cells in S phase with a concomitant slight increase in the G0/G1 phase. Simultaneously, a reduction in the cell population in the G2/M phase was observed under the influence of CELE and nfGO + CELE.

In HepG2 cells, in contrast to non-tumour cells, a decrease in the G0/G1 phase population, slight increase the $\mathrm{S}$ population, and an increase in the G2/M phase population under the influence of nfGO + CELE were observed.

Observation of C3A cells showed no effect of the graphene surface on the cell cycle, although the CELE and nfGO + CELE slightly increased the population of cells in the $\mathrm{S}$ phase and decreased the population of cells in the G2/M phase.

\section{Discussion}

Mutual interaction, signalling and cooperation between the ECM and the cell, and, moreover, the principle of feedback in these relationships are key factors determining the fate of the cell (Carloni et al. 2014; Iwasaki et al. 2016). In the present research, we wanted to clarify whether a change in the basic physicochemical parameters of the surface (mimic ECM) will change the behaviour of the cell, and especially whether it will reduce its carcinogenic potential. However, based on previous studies, we have shown that modification of the surface ECM, mainly by the effect of mechanotransduction, changes the cell's demand for functional molecules. Thus, the surface effect also depends, to a large extent, on the chemical compounds available to the cell, mainly proteins (Bałaban et al. 2020; Zielińska-Górska et al. 2020). Therefore, an attempt was made to force the cell to change its behaviour (weakening its invasiveness) by physicochemical modification of its niche together with supplying its environment with a wide spectrum of potentially useful proteins. For the first time, it has been shown that the use of mechanical stimulation (GO surface) with the addition of a protein cocktail can activate 


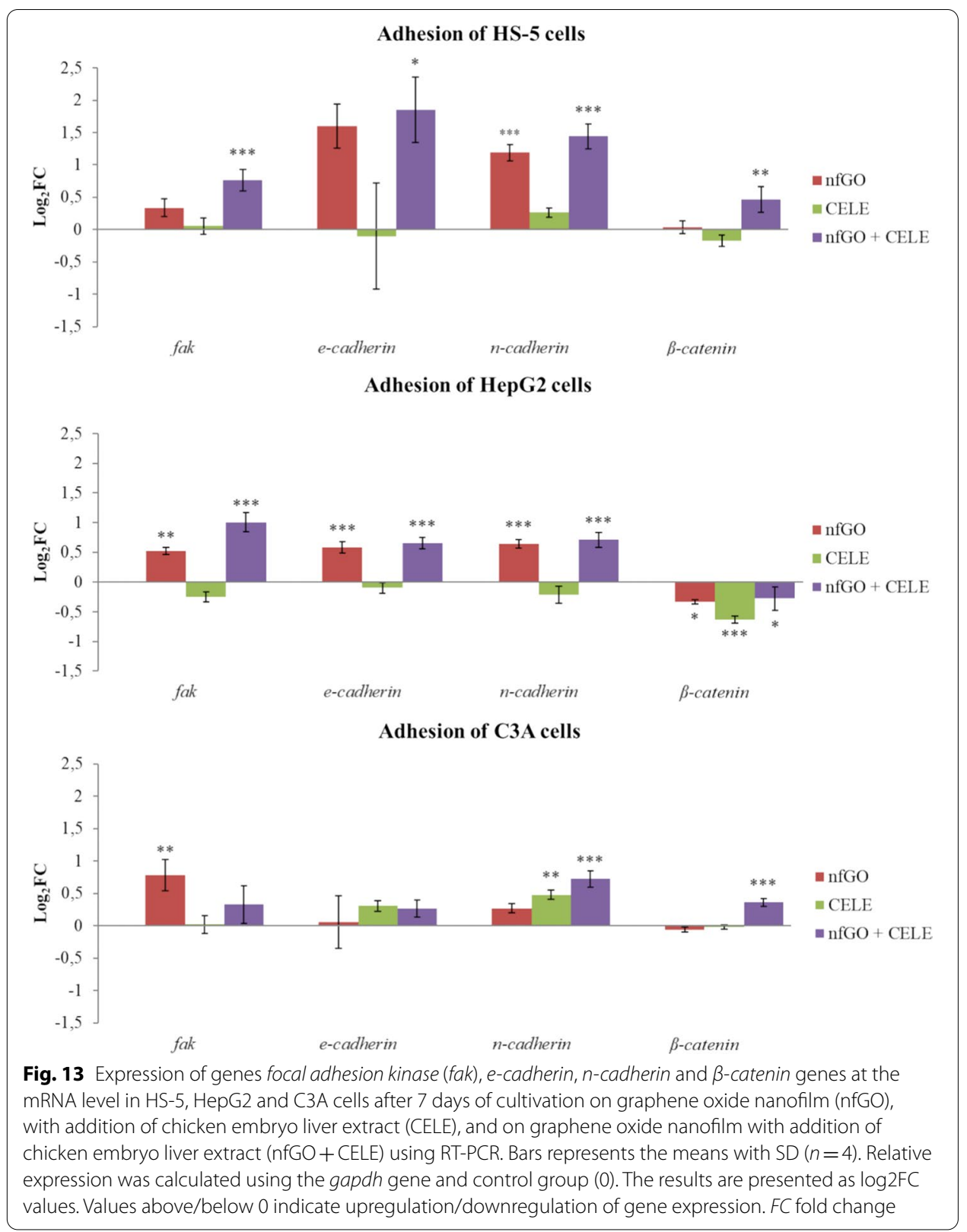

transmembrane signalling mechanisms and consequently decrease the proliferation of HepG2 liver cancer cells and reduce their carcinogenic potential.

In the present study, the surface of the culture plate was modified by a thin layer of GO which formed a nanofilm that could act on receptors located on the cell membrane but was not internalised by cells (Fiorillo et al. 2015). The newly created surface (nfGO) was a source of mechanical and chemical signal modification. The reduction of stiffness $(2.3 \mathrm{GPa})$ and the increase in roughness by the nfGO, compared to clean polystyrene (3-3.5 GPa) (Chaudhuri et al. 2016; Di Crescenzo et al. 2019), resembles the differences between normal and fibrotic tissue (Liu et al. 2015; Schrader et al. 2011). Moreover, the negative charge that characterised GO also favourably changed 

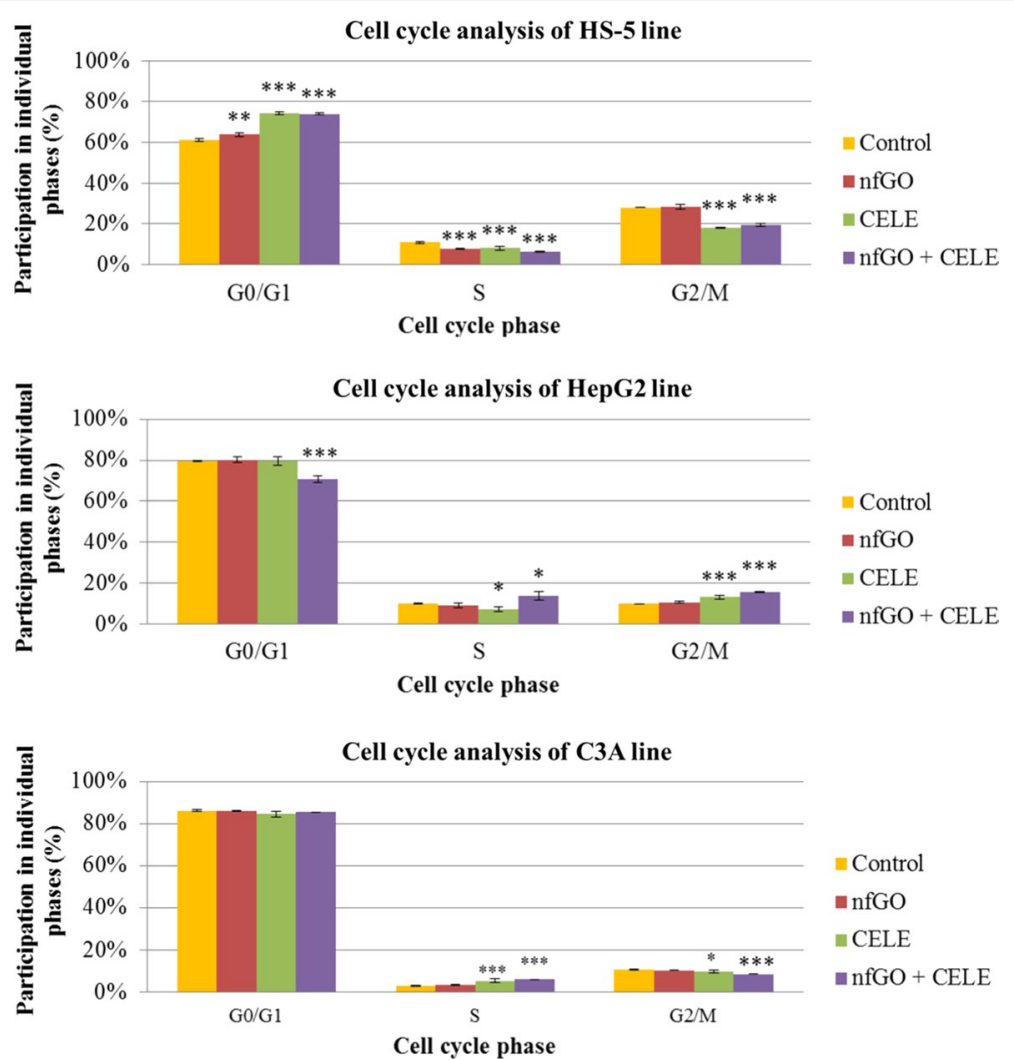

Fig. 14 Effect of graphene oxide nanofilm (nfGO), chicken embryo liver extract (CELE), and graphene oxide nanofilm with addition of chicken embryo liver extract (nfGO + CELE) on the number (percentage) of HS-5, HepG2, and C3A cells in G0/G1, S, and G2/M phases. Cell cycle analysis was performed using propidium iodide (PI) 488 assay

the surface that imitated the negative charge of proteoglycans and hyaluronic acid, as opposed to collagen (Kiew et al. 2016; Stylianopoulos et al. 2010). The beneficial change in GO surface properties also concerned increasing their hydrophilicity by the presence of numerous oxygen groups, such as hydroxyl $(-\mathrm{OH})$, carboxylic $(-\mathrm{COOH})$, and epoxide (-O-) (Kurantowicz et al. 2017).

The second factor, the source of the cocktail of various proteins, was chicken liver embryo extract. The unpredictable demand of cells for signalling growth-structural factors under the influence of the modified surface (mimic ECM) determined the choice of CELE. Namely, a unique phenomenon of embryo growth and development has been used, consisting, inter alia, in creating a perfect, dynamic niche for extremely fast proliferating cells (Walker et al. 2018; Mu et al. 2014; Jabaily and Singer 1978). Most of the proteins from CELE were part of the perfect ECM/niche. CELE provided two types of laminins (LAMA1 and LAMC1), whose level is reduced in HCC (Carloni et al. 2014), and also only two types of collagen (COL12A 1 and COL5A1) that are detected in healthy tissue but not in cancer tissue (Naba et al. 2014) as well as other important proteins include fibronectin (FN1) and vitronectin (VTN), which are responsible for the regenerative process (Klaas et al. 2016; Mayoral et al. 2005). The extract also contained functional proteins responsible for ECM modification, tight 
cellular connections, migration, EMT, and asymmetric cell division in embryogenesis and proliferation. However, the behaviour of the CELE proteins should be considered as a dynamically migrating and changing structures, and above all one that potentially interacts in two directions. The first is direct contact and signalling to the cell, while the second is depositing the nfGO and building the mimic ECM/niche structure (Chaudhuri et al. 2016; Essid et al. 2018). The high roughness of the graphene surface enriched with $\pi$ electrons can promote cell adhesion and adsorption of ECM proteins through noncovalent $\pi-\pi$ stacking interactions (Vernon et al. 2018; Xie et al. 2019) and form the so-called protein corona (Kopova et al. 2013; McCallion et al. 2016; Albanese et al. 2014).

The first line of contact between the cell and the ECM are integrins, which in response to signals from outside transmit information to the cell and are the source of the signalling cascade covering most of its functions (Carloni et al. 2014; Fu et al. 2007; Wang et al. 2011a, b). Integrins, heterodimeric receptors, belong to the family of adhesive proteins and contain 18 alpha subunits and 9 beta subunits occurring in 24 alpha-beta combinations (Humphries et al. 2006). However, a high level of expression of one subunit may be sufficient to alter the expression of the entire heterodimer (Arun et al. 2018). Nine key integrin subunits were identified in the conducted studies. Interestingly, the expression of examined integrins under the influence of both the surface and the CELE was definitely different in HepG2, C3A, and non-cancer HS-5 cells, which demonstrated the different sensitivity of various types of cells or/and tumours to mechanical and chemical signalling derived from the cell microenvironment. Thus, the mechanical characteristics of the substratum can be expressed due to the dynamics of integrin clusters in a cellspecific manner (Cheng et al. 2020). What's more, it confirms the thesis of the need for targeted therapy and the risk of obtaining a negative effect in mismatched therapy. Additionally, C3A cells cause a higher resistance to treatment than the HepG2 cell line (Sosnowska et al. 2019). C3A cells produce more albumin and alpha-fetoprotein than HepG2 cells and can grow in the glucose-deficient medium. Albumins and alpha-fetoprotein from C3A can adsorb onto nanomaterials, form protein corona, change the interaction nfGO-cells, and mitigate the effect of nfGO (Marchesan et al. 2014; Nguyen et al. 2018).

Integrins are involved in every stages of cancer progression, including cancer initiation and proliferation, local invasion and intravasation into vasculature, survival of circulating tumour cells, priming of the metastatic niche, extravasation into the secondary site and metastatic colonisation on the new site. Furthermore, integrins play a role in regulation of protease expression, transport and activation of white blood cells, chronic inflammation, angiogenesis and immune mimicry, and by which they determine disease state (Hamidi and Ivaska 2018). Studies on integrin expression still do not allow for an unambiguous arrangement of their role and significance depending on the type of cells, type of cancer and phenotype of cancer cells, stage of cancer, and metastasis. Discrepancies in information on integrins result from the heterogeneity of samples, the use of different methodologies to assess cancer advancement and, consequently, fluctuations in the expression of integrins at different stages of disease progression. It is now known that impaired expression of integrins affect the development of many cancers, i.e. acute lymphoblastic leukaemia, breast cancer, colorectal cancer, cervical cancer, oesophageal squamous cell carcinoma, gastric cancer, lung cancer, malignant melanoma, ovarian 
cancer and many others (Hamidi and Ivaska 2018). Nevertheless, numerous studies have allowed for the creation of a map of plausible integrin heterodimers as therapeutic cancer targets (Humphries et al. 2006). Most integrin genes are upregulated in HCC for example $\alpha 1$ integrin (Liu et al. 2002). However, studies have shown that reduced expression of some subunits, including $\alpha 2, \alpha 3, \alpha 5$ and $\beta 4$, occurs in HCC (Mayoral et al. 2005), malignant melanoma and breast cancer (Hamidi and Ivaska 2018). Our results show that the use of CELE and nfGO increased the expression of integrins that play a suppressor role. Based on the analysis of the expression of selected integrins in liver tumours compared to healthy tissue, $\alpha \mathrm{V}$ and $\beta 1$ subunits can be indicated as the most frequently recurring in typed heterodimers (Fu et al. 2007; Arun et al. 2018). In our studies, the expression of $\beta 1$ integrins did not change under the influence of the factors used in HepG2 cells, in contrast to C3A cells. This confirms the diverse response of different types of tumours and above all may suggest the procancerogenic activity of both nfGO and CELE for the C3A tumour line. Analysis of $\alpha V$ integrin expression also confirms the adverse effects of the CELE and nfGO in C3A cells. However, in HepG2 cells, the expression of integrin $\alpha V$ was lower under the influence of CELE, although higher under the influence of surface modification with GO nanofilm. Integrin $\alpha \mathrm{V}$ is upregulated in many tumour cells, making it a promising therapeutic target. Most integrins, including $\alpha \mathrm{V}$, can bind various ligands, e.g., fibronectin and vitronectin (Humphries et al. 2006). Despite the presence of these ligands in the extract, there was no increase in expression of the $\alpha V$ subunit, which is considered to be a marker of liver fibrosis. In addition, the extract reduced expression of the $\alpha 6$ subunit, which is involved in treatment resistance, spheroid and exosome formation, and metastasis (Mayoral et al. 2005; Wu et al. 2018). An inhibitor of $\alpha \mathrm{V}$ integrin is a new drug for the treatment of glioblastomas that is being verified in a phase III clinical trial (Arun et al. 2018). However, this therapeutic method of blocking integrin antibodies is not an excellent solution and is not always effective. The reason for the ineffectiveness of such a therapy may be that integrin overexpression may be a survival signal and result from feedback (ECM-cell) in which the cell does not adhere to a degraded niche, which in turn promotes metastasis (AldayParejo et al. 2019). Thus, the desperate attempt of the cell to contact the ECM/niche and consequently the increase of integrin expression may be greater the more its environment is degraded. Paradoxically, despite being a kind of "striving for normality", it is proportional to the carcinogenicity and metastasis potential. Moreover, most studies do not take into account the physicochemical state of the extracellular matrix, which is the largest regulator of integrin expression and activity, especially when faced with a very large number of ligands present in the ECM and cell surface adhesion proteins that bind integrins. The presence or absence of specific ligands in the ECM appears to be crucial for integrin expression and status. Culturing HepG2 cells on nfGO reduced the expression of the laminin binding $\alpha 3$ integrin and fibronectin binding $\alpha 5$ subunits in HepG2 cancer cells (Wang et al. 2011a, b). Laminin and fibronectin are involved in the formation of dynamic cell binding to ECM. Furthermore, they mediate cell binding to collagen (Walker et al. 2018). The $\alpha 5 \beta 1$ integrin is the most important fibronectin receptor that binds to RGD-containing peptides. It can be assumed that nfGO has become a structure that imitates laminin and fibronectin, becoming a surface that promotes HepG2 cell adhesion (Chaudhuri et al. 2016; Yu et al. 2019). Although it seems more likely that the 
protein corona, made up of proteins available in the culture medium, exposed ligandlike structures on the surface. However, by analysing the expression of $\alpha 5$, overexpression of this gene was observed when CELE was added to the culture medium. This expected effect was probably the result of the increased availability of ligands (fibronectin) in the culture medium, whose source was CELE, and activation of their binding to alpha 5 integrin, however, independent of the surface. Interestingly, surface modification and simultaneous addition of CELE increased the expression of the integrin $\alpha 5$ subunit, which can be explained by the increased availability of ligands through binding them to nfGO. The nfGO roughness was greater than the culture plastic plate, but also proteins' noncovalent $\pi-\pi$ stacking interactions (Vernon et al. 2018) could increase the amount of bottom-related proteins. Furthermore, this interaction could be preferentially directed to the RGD-mimicking GO motif due to tryptophan, which also has $\pi-\pi$ interactions due to the aromatic ring (Vernon et al. 2018; Koivunen et al. 1994). Moreover, the use of both factors enhanced expression of the $\alpha 5$ subunit to the greatest extent. This integrin is involved in cell strong adhesion, and thus we paid attention to the proteins involved in cell-ECM and cell-cell adhesion mechanisms.

Mechanotransduction resulting from integrin clustering dynamics, depending on the rigidity of the substrate, is associated with FAK phosphorylation (Cheng et al. 2020). The expression of $f a k$ increased in HS-5 and HepG2 cultivated on nfGO with CELE supplementation. GO may reduce (Wang et al. 2011a, b; Zhu et al. 2017) or enhance fak expression (Lasocka et al. 2019), which may depend on the presence of ligands, and consequently in our research, CELE was added to prevent this. Liver cells are anchor-dependent cells in which the level of $f a k$ increases in suspension culture (Cance et al. 2000; Shang et al. 2019; Ren et al. 2015). The tested cells adhered tightly to the surface, so overexpression of $f a k$ resulted from increased via integrin signalling, conditioned by strong cell adhesion to nfGO + CELE, and it could be a signal of cell survival in the proadhesive but antiproliferative niche (Bai et al. 2009).

The cadherin-catenin complex carries the mechanotransduction signal between the cytoplasm of neighbouring cells (Mui et al. 2016). High expression of E-cadherin is a characteristic feature of epithelial cells; it inhibits translocation of $\beta$-catenin into the nucleus and promotes better prognosis in cancer therapy (Zhang et al. 2017). Expression of adhesive protein genes such as $e$-cadherin and $n$-cadherin was higher under the influence of GO nanofilm and nfGO + CELE, especially in HepG2 cells, but most important was a reduction in $\beta$-catenin expression in these cells (Kim et al. 2019; Shang et al. 2019; Kasprzak et al. 2017). Our results, like Mu et al. (2014) showed that cells increase the expression of E-cadherin on nfGO, moreover, in view of the fact that the weakening of tight connections (E-cadherin expression) and an increase in flexible cell-cell contacts (N-cadherin expression) is characteristic of HCC (Mu et al. 2014). Thus, the increase in expression of two types of intercellular junctions suggests that the experimental factors used (nfGO and CELE) did not increase the invasion of HepG2 cells (Mu et al. 2014; Kasprzak et al. 2017; Luo et al. 2019). These results are also confirmed by the observation of cell morphology, which reflects the cell-ECM and cell-cell relationship and also indicates material biocompatibility (Jabaily and Singer 1978; Kurantowicz et al. 2015; Strojny et al. 2015; Szmidt et al. 2016). 
First of all, tendencies to form smaller cell clusters and a larger number of single cells strongly associated with the GO surface were observed in both HepG2 and C3A groups. This confirms the biocompatibility of the GO plane (Di Crescenzo et al. 2019) and also indicates one- and several-cell migration instead of collective migration, which is characteristic of abnormal ECM (Haeger et al. 2014). Furthermore, the roughness and elasticity of GO as a mimic ECM could advantageously imitate the natural ECM mosaic, and it was preferentially selected by all cells (Chaudhuri et al. 2016). The effect of CELE was slightly different for HS-5 cells and liver cancer cells. This may be due to the fact that it contained more ligands and other factors needed by the liver cell rather than the connective tissue cell. Our research and that of other authors may indicate that extracts from chicken embryo (Mu et al. 2014), zebrafish (Cucina et al. 2006), and amphibian oocyte (Allegrucci et al. 2011) are excellent cocktails of factors preventing metastatic phenotype.

External mechanical-chemical stimuli, received through integrin-dependent mechanisms transmitted to the cell, create a cascade of events that determine the fate and purpose of the cell. Analysing the cell cycle, it was observed that the population in G0/G1 phase decreased only in the case of HepG2 cells. Furthermore, mcm 2 and pcna gene analysis confirmed a decrease in cell population in G1 and S phases, respectively. pcna and $m c m 2$ gene products are involved in the DNA replication process as chaperons for polymerase. High expression of pcna at the mRNA level is observed in venous invasion of colorectal cancer with liver metastases (Yue et al. 2003). During hepatocarcinogenesis, most MCM family proteins are elevated, including MCM2, MCM6, MCM8, and MCM10. Research reports that MCM2 is a biomarker of esophageal and bladder cancer in initial diagnosis (Liu et al. 2018). Thus, reduction of proliferation markers expression, i.e. pcna and $m c m 2$, can protect against uncontrolled proliferation and relapses. Our research and Wang et al. (2011a, b) showed that overexpression of the $\alpha 5$ subunit inhibits the proliferation and invasiveness of cancer cells (Wang et al. 2011a, b). Therefore, proper cell adhesion overcame the first proliferation checkpoint, i.e. the transition from the G1 phase to the S phase (Moreno-Layseca and Streuli 2014). In most human cancers, the G0/G1 checkpoint does not completely stop the cell cycle as opposed to G2/M (Yin et al. 2017). In the present work, the use of CELE and also two factors (nfGO + CELE) increased the population of HepG2 cells in the G2/M phase, thus preventing cells with damaged DNA from entering the $M$ phase and allowing damage repair (Sosnowska et al. 2019). Ultimately, the total population of HepG2 cells in the active phase of the cell cycle was increased, in particular in G2/M phase. The ki67 is a prognostic indicator of patients' survival and is more strongly expressed in malignant, rapidly proliferating cells than in normal cells. Moreover, high ki67 expression correlates with metastases and poor prognosis for breast, lung, intestine and prostate cancer (Li et al. 2015; Guzman et al. 2005) and with relapses after hepatectomy (Li et al. 2018). Therefore, there are studies on blocking ki67 using siRNA and anti-ki67 antibodies (Li et al. 2015). The use of both factors caused cell cycle arrest in the G2/M phase, the phase in which ki67 is most expressed. Moreover, many extract proteins (including nitrilase 2 (NIT2), DNA-binding protein 43 (TARDBP) and dynein light chain) adsorbed on nfGO or available in the medium may have been involved in arresting the cell cycle in the G2/M phase (Cucina et al. 2006; Lin et al. 2007; Lee et al. 2012). Our results and Jabaily et al. (1978) confirm 
that liver extract was a universal source of missing proteins, and in the future, it may modulate the proliferation of various cell lines including bone marrow and muscle cells (Jabaily and Singer 1978). The final and fundamental evidence of the loss of HepG2 cell invasiveness is a reduction of proliferation in the BrdU test of more than $40 \%$ compared to the control, which was not observed in non-cancerous cells.

All of these data indicate that graphene oxide and a cocktail of proteins that formed the dynamically changing proteome of the cell environment, migrating in the culture medium to the GO plane and the cell and therefore available multilevel (as a source of ligands and other proteins and as a modulator of the chemical characteristics of the graphene surface), may have therapeutic effects on HepG2 liver cancer. ECM therapy may have the effect of supporting traditional treatment, especially since degraded ECM characteristic for tumours becomes a pro-tumour factor and, in any case, hinders treatment.

\section{Conclusions}

In the present study, we indicated the possibility of using the so-called ECM therapy as an option to support the treatment of some cases of liver cancer. For the first time, it has been documented that for the HepG2 cancer cell line, the use of mimic ECM in the form of a graphene oxide nanofilm enriched with a natural protein cocktail, being the source of ligands for integrins and a wide range of other missing proteins, is the source of a mechano-chemo transduction signal. This signal, via integrin expression, adhesion, morphology change, and cell cycle arrest in the G2/M phase, reduces the proliferation of tumour cells. The research is preliminary and requires further precise experiments.

\section{Methods}

Characterisation of GO nanoparticles and GO nanofilms Characterisation of GO nanoparticles

GO flakes, as a water dispersion at a concentration of $4 \mathrm{mg} / \mathrm{mL}$, were purchased from NANOPOZ (Poznan, Poland) and produced by the modified Hummers method. This nanomaterial, after dispersion into ultrapure Milli-Q water to prepare $50 \mathrm{mg} / \mathrm{L}$ solutions, was sonicated for $15 \mathrm{~min}$ in an ultrasonic bath (Bandelin Electronic, Berlin, Germany) to avoid agglomeration. The shape and size of the GO flakes were characterised using transmission electron microscopy (TEM: JEM-1220 JEOL, Tokyo, Japan). TEM was connected to a camera (SIS Morada 11 megapixels) and operated by ITEM Olympus Soft Imaging Platform. Six pictures were taken of two independent samples. Zeta potential was measured in triplicate with a Nano-ZS90 Zetasizer (Malvern Instruments, Malvern, UK) operated by Zetasizer software 7.13.

The Fourier transform infrared spectra of GO were acquired using a Perkin Elmer System 2000 instrument (MA, USA) operated by Pegrams software in the range of 400$4000 \mathrm{~cm}^{-1}$. Solid-state samples were milled with potassium bromide $(\mathrm{KBr})$ crystals in an approximate ratio of 1:300 $\mathrm{mg}$. The solid mixture was milled in a laboratory mill (Specac) to obtain a fine powder. Then, 8 tons of pressure was applied for $2 \mathrm{~min}$ to prepare transparent thin pellets. A total of 25 scans were conducted for every sample. The infrared absorption of water vapour and carbon dioxide was mostly eliminated. Spectra were processed with baseline correction and Fourier smoothing, with 90\% smoothing, 
to remove undesired noise. Spectra are presented as transmission (dependent variable) against wavenumber (independent variable).

\section{Preparation and characterisation of GO nanofilms}

A GO aqueous solution $(1000 \mathrm{mg} / \mathrm{L})$ was sonicated for $30 \mathrm{~min}$ before preparing the nanofilm. GO was used to form nanofilms by applying the solution to the bottom of ordinary polystyrene plates (353046, Falcon, Tewksbury, MA, USA) (Sawosz et al. 2017). A GO solution was dried at room temperature in a laminar chamber for day. A $1 \mathrm{~cm}^{2}$ polystyrene surface was covered with $105 \mu \mathrm{g}$ of carbon solution. As a result of selfassembly, the resultant surface was a stable, multilayer, thin nanofilm that adhered perfectly to the bottom of the plastic wells. Thus, GO coating was deposited on polystyrene plates by solvent evaporation from graphene nanoflake solutions. However, the nanofilm could be damaged when taking it out.

The AFM method (Nanosurf, Liestal, Switzerland) was used to characterise the morphology of the plastic plate and GO coated plate including average roughness and maximum height of the roughness. Six pictures were taken of two independent samples.

The water contact surface on an uncoated and GO coated surface was measured by the sessile drop technique, i.e. a $20-\mu \mathrm{L}$ drop of water was placed on the investigated surface and a picture was taken. Five measurements of the contact surface were detected to characterise the GO film wettability during liquid spreading and dewetting using a stereomicroscope (SZX10, CellD software version 3.1; Olympus Corporation, Japan). Water area $\left(\mathrm{mm}^{2}\right)$ was calculated using Image ${ }^{\circledR} 1.48 \mathrm{v}$ (National Institutes of Health, Bethesda, MD, USA).

To evaluate the preferences of cell placement on and outside the nanofilm, the GO colloidal solution partially coated the culture plate. After nfGO was dried, we were able to observe cell migration and the affinity of cells to the nanofilms using SEM.

\section{Preparation and characterisation of extract (CELE)}

Preparation of CELE and bicinchoninic acid protein assay (BCA)

Livers from 10-day chicken embryos were removed and used for protein isolation. Whole-liver protein extracts were prepared with a TissueLyser LT instrument (Qiagen, Hilden, Germany) using $8 \mathrm{~g}$ of tissue and $20 \mathrm{~mL}$ of Milli-Q water. The homogenate was centrifuged at $3000 \mathrm{rpm}$ for $10 \mathrm{~min}$. The precipitate was removed, and the supernatant was transferred to new tubes. The total protein content was determined in six repetitions using a BCA Protein Assay Kit according to the manufacturer's recommendations (Sigma-Aldrich, St. Louis, MO, USA). The extract was added at a volume ratio of $1 \mathrm{~mL}$ of extract per $100 \mathrm{~mL}$ of Dulbecco's modified Eagle's me (DMEM) to obtain a 1\% extract in DMEM.

\section{Mass spectrometry}

Protein extract $(150 \mu \mathrm{L}, 24.6 \mathrm{mg} / \mathrm{mL})$ was concentrated using Vivacon 500, 10000 MWCO hydrosart filters and washed twice. Proteins were reduced by the addition of $50 \mu \mathrm{L}$ of washing buffer ( $8 \mathrm{M}$ urea in $100 \mathrm{mM} \mathrm{NH}_{4} \mathrm{HCO}_{3}$ aqueous solution) with $20 \mathrm{mM}$ tris(2-carboxyethyl) phosphine and incubated for $30 \mathrm{~min}$. After centrifugation, proteins were alkylated with $50 \mu \mathrm{L}$ of $20 \mathrm{mM}$ indole-3-acetic acid in washing buffer and then 
spun. Digestion was performed with the protease mix LysC/Tryp (V507A, Promega, Madison, WI, USA). First, $40 \mu \mathrm{L}$ of a solution was added to the filter and incubated for $3 \mathrm{~h}$ at $37{ }^{\circ} \mathrm{C}$, and then, $400 \mu \mathrm{L}$ of $\mathrm{NH}_{4} \mathrm{HCO}_{3}$ was added, and samples were incubated overnight at $37{ }^{\circ} \mathrm{C}$. After centrifugation, the solution was acidified with a final concentration of $0.4 \%$ trifluoroacetic acid (TFA) and speed-vacuumed to dryness. The peptide mixture was fractionated using a high $\mathrm{pH}$ protocol on an Oasis HLB $10 \mathrm{mg}$ cartridge (Waters 186000383). Cartridges were activated by washing with methanol and equilibrated with $25 \mathrm{mM}$ ammonium formate, $\mathrm{pH}$ 10. The protein pellet was resuspended in $400 \mu \mathrm{L}$ of 25 ammonium formate ( $\mathrm{pH} 10)$ and loaded on a cartridge. The elution was carried out with an increasing gradient of acetonitrile in loading buffer and with pure methanol (last elution). All fractions were dried, and pellets were resuspended in $60 \mu \mathrm{L}$ of $0.1 \%$ TFA with $2 \%$ MeCN. MS analysis was performed via LC-MS in the Laboratory of Mass Spectrometry (IBB PAS, Warsaw) using a nanoAcquity UPLC system (Waters) coupled to an LTQ-Orbitrap Q Exactive mass spectrometer (Thermo Fisher Scientific, Waltham, MA, USA). The mass spectrometer was operated in the data-dependent MS2 mode, and data were acquired in the $\mathrm{m} / \mathrm{z}$ range of $200-2000$. Peptides were separated by a 180 min linear gradient of $95 \%$ solution A ( $0.1 \%$ formic acid in water) to $45 \%$ solution $B$ (acetonitrile and $0.1 \%$ formic acid). The measurement of each sample was preceded by three washing runs to avoid cross-contamination. Data were analysed with the MaxQuant 1.6.3.4 platform (Cox and Mann 2008; Tyanova et al. 2015). The Gallus gallus reference proteome database from UniProt was used.

\section{Interference spectra of GO with CELE}

To obtain the interference spectra of the two factors, GO aqueous solution $(1000 \mathrm{mg} / \mathrm{L})$ were mixed with DMEM containing 1\% CELE in ratio 1:2. Mixture was incubated at $37{ }^{\circ} \mathrm{C}$ overnight. The next day, mixture was centrifuged at $2000 \mathrm{rpm}$ for $10 \mathrm{~min}$ and washed to get rid of proteins not bound to GO. The Fourier transform infrared spectra of nfGO + CELE were acquired using a Perkin Elmer System 2000 instrument as previously described.

\section{Cell cultures and treatments}

The liver cancer cell lines HepG2 (HB-8065) and C3A (CRL-10741) and the non-cancer bone marrow stromal cell line HS-5 (CRL-11882) were obtained from ATCC (Manassas, VA, USA). Cell cultures were maintained at $37{ }^{\circ} \mathrm{C}$ under $5 \% \mathrm{CO}_{2}$ in DMEM, Low Glucose (Gibco, Thermo Fisher Scientific) supplemented with $10 \%$ foetal bovine serum (FBS, Thermo Fisher Scientific), penicillin $(100 \mathrm{U} / \mathrm{mL})$, and streptomycin $(100 \mathrm{mg} / \mathrm{mL}$, Thermo Fisher Scientific). Cells were seeded on 6 -well plates $\left(1.5 \times 10^{5}\right.$ cells in each well), and the cultures were maintained for $48 \mathrm{~h}$ and 7 days.

All experiments were conducted according to the following scheme: (1) no treatment group-control; (2) group using the nfGO; (3) group with the addition of CELE in an amount of $1 \%$ of the culture medium-CELE; (4) group using the nfGO with the addition of CELE in an amount of $1 \%$ of the culture medium-nfGO + CELE. CELE components were added as serum-like supplements to medium. The medium containing CELE was incubated on nfGO at $22^{\circ} \mathrm{C}$ for $5 \mathrm{~min}$. Finally, the cells were added onto the CELEloaded nfGO. 


\section{MTT assay}

Viability assessment of cells cultivated on the nfGO and/or with the addition of CELE was performed using MTT assay (No. ab211091, Abcam, Cambridge, UK). Cells were seeded on the 96-well microplates at a concentration $2 \times 10^{4}$ cells/well. All of the treatment groups were examined in six repetition. Cells were cultured for $48 \mathrm{~h}$, and then DMEM was removed. Serum free DMEM $(50 \mu \mathrm{L})$ and MTT reagent $(50 \mu \mathrm{L})$ were added into each well. After $3 \mathrm{~h}$ at $37{ }^{\circ} \mathrm{C}$, mixture containing DMEM and MTT was removed and cells were lysed using $150 \mu \mathrm{L}$ of MTT solvent. The results were examined using Tecan Infinite 200 microplate reader (Tecan, Durham, NC, USA) at $590 \mathrm{~nm}$.

\section{BrdU assay}

Cell proliferation was studied using a bromodeoxyuridine (BrdU) incorporation assay (BrdU colorimetric) (Roche Applied Science, Indianapolis, IN, USA). HS-5, HepG2, and C3A cells were seeded in the 96-well microplates according to the scheme described in the "Cell cultures and treatments" section at a concentration $7 \times 10^{3}$ cells/well. All of the treatment groups were examined in six repetitions. Cells were cultivated for $24 \mathrm{~h}$, and then $20 \mu \mathrm{L}$ of $100 \mu \mathrm{M}$ BrdU solution in DMEM was added to each well of the cultured cells. The cells were labelled with BrdU for $24 \mathrm{~h}$. All further steps were carried out according to the manufacturer's instructions. Cell proliferation was analysed using a Tecan Infinite 200 microplate reader at $370 \mathrm{~nm}$ with a reference wavelength of $492 \mathrm{~nm}$.

\section{Microscopy}

\section{Light microscopy}

To assess cell morphology, an inverted light microscope (Leica, TL-LED, Wetzlar, Germany) was used. The instrument was connected to a digital camera (Leica MC190 HD) and operated with LAS V4.10 software (Leica). The cells were stained using haematoxylin-eosin after $48 \mathrm{~h}$ of incubation. Six pictures were taken of two independent samples. Morphometric analysis of $10 \times$ magnification images was performed using the Image J software.

Cell invasion was assessed using culture-insert 2 well (No. 80209, Animalab, Germany) in 6-well plate. The total area of 6-well plate was uncoated (control, CELE) or coated by nfGO (nfGO, nfGO + CELE). Cells were seeded at a concentration $5 \times 10^{4}$ cells/well and cultivated in culture-insert 2 well to achieve a monolayer. The growth area in culture-insert was $0.22 \mathrm{~cm}^{2}$ per well. Width of cell free gap was $500 \mu \mathrm{m} \pm 100 \mu \mathrm{m}$. After $24 \mathrm{~h}$ of incubation, inserts were removed, and the cell layer was washed with PBS. The plate was filled with $2 \mathrm{~mL}$ of medium in each well, and cells were cultivated for $48 \mathrm{~h}$. Cells were fixed with methanol and stained with hematoxylin-eosin. Photographs were taken at the same area at $10 \times$ magnification of the wound using inverted light microscope. Images analysis was performed using ImageJ.

\section{Scanning electron microscopy}

Microstructures of cell morphology were evaluated using SEM. HS-5, HepG2 and C3A cells were seeded on 6-well plates uncoated and coated with nfGO. After 7 days 
of exposure, the cells were rinsed in phosphate-buffered saline (PBS, pH 7.2) and then fixed in $2.5 \%$ glutaraldehyde (G5882, Sigma-Aldrich) for $20 \mathrm{~min}$. Cells were incubated in osmium tetroxide $\left(\mathrm{OsO}_{4}\right)$ and then in freshly made $1 \%$ carbohydrazide and fixed again in $\mathrm{OsO}_{4}$ for $30 \mathrm{~min}$. After thorough rinsing, the plates were cut to fit the critical point dryer (Polaron CPD 7501, Quorum Technologies, Laughton, UK). Cells were dehydrated through a hexylene glycol series (Sigma-Aldrich). Samples were placed on aluminium SEM stubs. Six pictures were taken of two independent samples.

\section{Flow cytometry}

The cell cycle was evaluated using flow cytometry (FACSCalibur, Becton Dickinson, Franklin Lakes, NJ, USA). Cell cycle analysis, based on DNA content, was performed according to the UC San Diego Health Sciences (2019), using CellQuest Pro software. Cells were cultured in 6-well plates for one week as described in "Cell cultures and treatments" section. Cells were detached with trypsin, which was neutralised with fresh DMEM. After centrifugation, cell pellets were washed, resuspended in PBS (1 mL), fixed with 9 volumes of $70 \%$ ethanol at $4{ }^{\circ} \mathrm{C}$ for $24 \mathrm{~h}$. For propidium iodide (PI, $500 \mu \mathrm{g} / \mathrm{mL}$ ) staining, after centrifugation, each sample of cells was resuspended in $500 \mu \mathrm{L}$ of staining solution. The staining solution contained RNAse A ( $2 \mu \mathrm{L}$, Thermo Fisher Scientific), PI (20 $\mu \mathrm{L}$, Thermo Fisher Scientific), Tween $20(0.5 \mu \mathrm{L})$, and PBS $(477.5 \mu \mathrm{l})$. After incubation for $30 \mathrm{~min}$, the cells were analysed by flow cytometry by measuring the fluorescence emission at $530 \mathrm{~nm}$ and $575 \mathrm{~nm}$ (or equivalent) using excitation at $488 \mathrm{~nm}$. Each measurement was repeated three times.

\section{Gene expression}

\section{RNA isolation}

Cell cultures were maintained according to the previously described scheme. After 7 days of incubation, cells in 6-well plates were detached with trypsin and collected by centrifugation. All steps of RNA isolation were performed according to the protocol from the manufacturer Macherey-Nagel (No. 740955.250, Düren, Germany). The RNA concentration in each sample after isolation was determined using a NanoDrop 2000 spectrophotometer (Thermo Fisher Scientific). RNA was stored at $-80^{\circ} \mathrm{C}$.

\section{DNA synthesis}

The RNA level in all samples was equalised, and $10 \mu \mathrm{L}$ of RNA mixture in water was used for cDNA synthesis using a High-Capacity cDNA Reverse Transcription Kit (No. 4368814, Applied Biosystems, Foster City, CA, USA). The procedure was performed according to the manufacturer's protocol with the following cycle conditions: $10 \mathrm{~min}$ at $25{ }^{\circ} \mathrm{C}, 120 \mathrm{~min}$ at $37^{\circ} \mathrm{C}$ and store at $4{ }^{\circ} \mathrm{C}$. cDNA synthesis was performed using a 2720 Thermal Cycler (Thermo Fisher Scientific). ssDNA concentration was measured with the NanoDrop 2000 (Thermo Fisher Scientific), and $300 \mu \mathrm{L}$ of $20 \mathrm{ng} / \mu \mathrm{L}$ ssDNA was prepared. ssDNA samples were kept at $-20^{\circ} \mathrm{C}$.

$R T-P C R$ Gene expression at the mRNA level was measured using the $\triangle \triangle C T$ relative quantification real-time PCR method. The reaction mixture was prepared using Power SYBR $^{\mathrm{TM}}$ Green PCR Master Mix (Thermo Fisher Scientific), $10 \mu \mathrm{M}$ forward primers, 
Table 3 Primers used to evaluate the expression of genes involved in proliferation and cell adhesion

\begin{tabular}{|c|c|c|c|c|}
\hline Gene & Sequence of primer $5^{\prime} \rightarrow 3^{\prime}$ & $\begin{array}{l}\text { Amplicon } \\
\text { size (bp) }\end{array}$ & $\begin{array}{l}\text { GenBank accession } \\
\text { number }\end{array}$ & References \\
\hline pena & $\begin{array}{l}\text { F: CCATCCTCAAGAAGGTGT } \\
\text { TGG } \\
\text { R: GTGTCCCATATCCGCAAT } \\
\text { TTTAT }\end{array}$ & 710 & NM_182649.2 & PrimerBlast \\
\hline ki67 & $\begin{array}{l}\text { F: CCACACTGTGTCGTCGTTTG } \\
\text { R: CCGTGCGCTTATCCATTCA }\end{array}$ & 123 & NM_001145966.2 & Szczepaniak et al. (2018) \\
\hline $\mathrm{mcm} 2$ & $\begin{array}{l}\text { F: GTGGATAAGGCTCGTCAGAT } \\
\text { R: GTCGTGGCTGAACTTGTT }\end{array}$ & 87 & NM_004526.4 & Szczepaniak et al. (2018) \\
\hline al & $\begin{array}{l}\text { F: GGTTCCTACTTTGGCAGT } \\
\text { ATT } \\
\text { R: AACCTTGTCTGATTGAGA } \\
\text { GCA }\end{array}$ & 149 & NM_181501.2 & Dingemans et al. (2010) \\
\hline$a 2$ & $\begin{array}{l}\text { F: GGAACGGGACTTTCGCAT } \\
\text { R: GGTACTTCGGCTTTCTCA } \\
\text { TCA }\end{array}$ & 154 & NM_002203.4 & Dingemans et al. (2010) \\
\hline a3 & $\begin{array}{l}\text { F: AAGGGACCTTCAGGTGCA } \\
\text { R: TGTAGCCGGTGATTTACCAT }\end{array}$ & 129 & NM_002204.4 & Dingemans et al. (2010) \\
\hline$a 4$ & $\begin{array}{l}\text { F: GCTTCTCAGATCTGCTCGTG } \\
\text { R: GTCACTTCCAACGAGGTT } \\
\text { TG }\end{array}$ & 131 & NM_000885.6 & Dingemans et al. (2010) \\
\hline a5 & $\begin{array}{l}\text { F: TGCAGTGTGAGGCTGTGT } \\
\text { ACA } \\
\text { R: GTGGCCACCTGACGCTCT }\end{array}$ & 88 & NM_002205.5 & Dingemans et al. (2010) \\
\hline$a 6$ & $\begin{array}{l}\text { F: TTGAATATACTGCTAACC } \\
\text { CCG } \\
\text { R: TCGAAACTGAACTCTTGA } \\
\text { GGATAG }\end{array}$ & 113 & NM_000210.4 & Dingemans et al. (2010) \\
\hline$a V$ & $\begin{array}{l}\text { F: AATCTTCCAATTGAGGAT } \\
\text { ATCAC } \\
\text { R: AAAACAGCCAGTAGCAAC } \\
\text { AAT }\end{array}$ & 140 & NM_001145000.3 & Dingemans et al. (2010) \\
\hline$\beta 1$ & $\begin{array}{l}\text { F: GAAGGGTTGCCCTCCAGA } \\
\text { R: GCTTGAGCTTCTCTGCTGTT }\end{array}$ & 107 & NM_002211.4 & Dingemans et al. (2010) \\
\hline$\beta 4$ & $\begin{array}{l}\text { F: AGACGAGATGTTCAGGGA } \\
\text { CC } \\
\text { R: GGTCTCCTCTGTGATTTG } \\
\text { GAA }\end{array}$ & 115 & NM_001321123.2 & Dingemans et al. (2010) \\
\hline Fak & $\begin{array}{l}\text { F: CCCACCAGAGGAGTATGT } \\
\text { CC } \\
\text { R: CCCAGGTCAGAGTTCAAT } \\
\text { AG }\end{array}$ & 150 & XM_017013688.2 & Chen et al. (2012) \\
\hline e-cadherin & $\begin{array}{l}\text { F: ACAACGCCCCCATACCAGA } \\
\text { R: CACTCGCCCCGTGTGTTAGT }\end{array}$ & 138 & NM_001317185.2 & PrimerBlast \\
\hline n-cadherin & $\begin{array}{l}\text { F: ACAGATGTGGACAGGATT } \\
\text { GTGGGT } \\
\text { R: TATCCCGGCGTTTCATCC } \\
\text { ATACCA }\end{array}$ & 124 & NM_001308176.2 & PrimerBlast \\
\hline$\beta$-catenin & $\begin{array}{l}\text { F: CCTATGCAGGGGTGGTCA } \\
\text { AC } \\
\text { R: CGACCTGGAAAACGCCAT } \\
\text { CA }\end{array}$ & 95 & NM_001012329.2 & PrimerBlast \\
\hline gapdh & $\begin{array}{l}\text { F: GAGAAGGCTGGGGCTCAT } \\
\text { TTG } \\
\text { R: CATGGTTCACACCCATG }\end{array}$ & 97 & NM_002046 & PrimerBlast \\
\hline
\end{tabular}


$10 \mu \mathrm{M}$ reverse primers, and RNase/DNase-free water at a ratio of 10:1:1:1.3. Then, $5 \mu \mathrm{L}$ of $100 \mathrm{ng}$ of ssDNA was added to $10 \mu \mathrm{L}$ of the reaction mixture. The primers used for realtime PCR are presented in Table 3. Glyceraldehyde-3-phosphate dehydrogenase (gapdh) was used as the reference house-keeping gene. The study was performed using a StepOnePlus ${ }^{\mathrm{TM}}$ Real-Time PCR System (Thermo Fisher Scientific) with the following settings: $95{ }^{\circ} \mathrm{C}$ for $10 \mathrm{~min}$, followed by 40 cycles of $95^{\circ} \mathrm{C}$ for $15 \mathrm{~s}$ and $60{ }^{\circ} \mathrm{C}$ for $60 \mathrm{~s}$. StepOneTM Software 2.2.2 was used to asses gene expression. All reactions were performed in triplicate, and the experiment was run two independent times. The $\triangle \mathrm{CT}$ value was calculated from the formula CT gene - CT GAPDH and used to investigate statistical significance. The $-\Delta \Delta \mathrm{CT}$ value is expressed as the relative gene expression $(\Delta \mathrm{CT}$ control $-\Delta \mathrm{CT}$ treated group).

\title{
Statistical analysis
}

The data were analysed using analysis of variance-ANOVA (for analysis of more than two research groups) or an unpaired t-test using GraphPad Prism software version 8.1.2 (GraphPad Software Inc., La Jolla, CA, USA). The differences between the groups determined by ANOVA were assessed with Bonferroni's multiple comparisons test. Differences with a $p$-value $\leq 0.05$ were defined as statistically significant compared to the control group: one asterisk $(*), p$-value $<0.05$; two asterisks $(* *), p$-value $<0.01$; three asterisks ${ }^{(* * *)}$, $p$-value $<0.001$.

\section{Supplementary Information}

The online version contains supplementary material available at https://doi.org/10.1186/s12645-020-00073-5.

\begin{abstract}
Additional file 1: Figure S1. Fourier transform infrared spectrum of chicken embryo liver extract (top) and graphene oxide nanofilm with addition of chicken embryo lever extract (bottom). Figure S2. Cell migration of HS-5 cells on modified surface after removing the insert ( $0 \mathrm{~h}$ ) and after $24,48,72 \mathrm{~h}$ of incubation (scratch wound healing assay). Figure S3. Cell migration of HepG2 cells on modified surface after removing the insert $(0 \mathrm{~h})$ and after $24,48,72 \mathrm{~h}$ of incubation (scratch wound healing assay). Figure $\mathbf{S 4}$. Cell migration of C3A cells on modified surface after removing the insert ( $0 \mathrm{~h}$ ) and after 24, 48, $72 \mathrm{~h}$ of incubation (scratch wound healing assay). Table $\mathbf{S 1}$. Wound closure rate of HS-5, HepG2 and C3A cells on modified surface. Results are expressed as percentage intercellular spaces based on ImageJ analysis. Table S2. Changes in HS-5, HepG2 and C3A cell viability using the MTT assay. Table S3. Changes in HS-5, HepG2 and C3A cell proliferation using the BrdU assay. Table S4. Changes in the expression of proliferation ( $\mathrm{cna}, \mathrm{ki67}, \mathrm{mcm} 2)$ and adhesion markers (integrins, cadherins, focal adhesion kinase and catenine) in HS-5 cells by real-time PCR (one way ANOVA). The results are presented as FC values, and untreated cells are depicted as 1. Values above/below 1 indicate upregulation/downregulation of gene expression. Abbreviations: FC, fold change. Table S5. Changes in the expression of proliferation ( $p c n a, k i 67, m c m 2)$ and adhesion markers (integrins, cadherins, focal adhesion kinase and catenine) in HepG2 cells by real-time PCR (one way ANOVA). The results are presented as FC values, and untreated cells are depicted as 1 . Values above/below 1 indicate upregulation/downregulation of gene expression. Abbreviations: FC, fold change. Table S6. Changes in the expression of proliferation ( $p c n a, k i 67, \mathrm{mcm} 2$ ) and adhesion markers (integrins, cadherins, focal adhesion kinase and catenine) in C3A cells by real-time PCR (one way ANOVA). The results are presented as FC values, and untreated cells are depicted as 1. Values above/below 1 indicate upregulation/downregulation of gene expression. Abbreviations: FC, fold change. Table S7. Cell cycle changes of HS-5, HepG2 and C3A cells using the flow cytometry. Table S8. Changes in the expression of proliferation (pcna, ki67, $\mathrm{mcm} 2$ ) and adhesion markers (integrins, cadherins, focal adhesion kinase and catenine) in HepG2 and C3A cells using two-way analysis of variance. The results are presented as FC values, and untreated cells are depicted as 1. Values above/below 1 indicate upregulation/downregulation of gene expression. Abbreviations: FC, fold change
\end{abstract}

\section{Abbreviations}

AFM: Atomic force microscopy; ANOVA: Analysis of variance; ATCC: American Type Culture Collection; BCA: Bicinchoninic acid protein assay; BrdU: Bromodeoxyuridine; CELE: Chicken embryo liver extract; Col12A1: Collagen alpha-1(XII) chain; Col14A: Collagen alpha(XIV) chain; Col16A: Collagen alpha(XVI) chain; Col5A1: Collagen alpha-1(V) chain; DMEM: Dulbecco's modified Eagle's medium; ECM: Extracellular matrix; EGFR: Epidermal growth factor receptor; EMT: Epithelial-mesenchymal transition; FAK: Focal adhesion kinase; FBS: Foetal bovine serum; FN1: Fibronectin; FTIR: Fourier transform infrared; GAPDH: Glyceraldehyde-3-phosphate dehydrogenase; H\&E: Hematoxylin and eosin; HBV: Hepatitis B virus; HCC: Hepatocellular carcinoma; HCV: Hepatitis C virus; LAMA1: Laminin subunit alpha-1; LAMC1: Laminin subunit 
gamma-1; MCM2: Minichromosome maintenance protein complex 2; nfGO: Graphene oxide nanofilm; NIT2: Nitrilase 2; PBS: Phosphate-buffered saline; PCNA: Proliferating cell nuclear antigen; PI: Propidium iodide; SEM: Scanning electron microscopy; TARDBP: DNA-binding protein 43; TEM: Transmission electron microscopy; TFA: Trifluoroacetic acid; VEGFR: Vascular endothelial growth factor; VTN: Vitronectin.

\section{Acknowledgements}

This report is a part of Malwina Sosnowska's PhD thesis.

\section{Authors' contributions}

Conceptualisation: MS, ES and MK. Methodology: MS, SJ and MK. Software: ES. Validation: MS, ES and MK. Formal analysis: MS and AC. Investigation: MS, BS, JS, PK and JB. Resources: ES, MS, MK and WB. Data curation: MS and KD. Writing - original draft preparation: MS. Writing — review and editing: ES, WB and AC. Visualisation: MS. Supervision: ES. Project administration: AC. Funding acquisition: MS and WB. All authors read and approved the final manuscript.

\section{Funding}

This research was carried out in the framework of project National Science Centre Poland nr. 2019/33/N/NZ7/01392.

\section{Availability of data and materials}

The datasets used and/or analysed during the current study are available from the corresponding author on reasonable request.

Ethics approval and consent to participate

Not applicable.

\section{Consent for publication}

Not applicable.

\section{Competing interests}

The authors declare that they have no competing interests.

\section{Author details}

${ }^{1}$ Department of Nanobiotechnology and Experimental Ecology, Institute of Biology, Warsaw University of Life Sciences, Warsaw, Poland. ${ }^{2}$ Faculty of Chemistry, Institute of Food Sciences, Warsaw University of Life Sciences, Warsaw, Poland.

${ }^{3}$ Department of Veterinary and Animal Sciences, University of Copenhagen, Copenhagen, Denmark. ${ }^{4}$ Department of Biochemistry and Microbiology, Institute of Biology, Warsaw University of Life Sciences, Warsaw, Poland.

Received: 19 September 2020 Accepted: 12 December 2020

Published online: 06 January 2021

\section{References}

Albanese A, Walkey CD, Olsen JB, Guo H, Emili A, Chan WCW. Secreted biomolecules alter the biological identity and cellular interactions of nanoparticles. ACS Nano. 2014;8(6):5515-26. https://doi.org/10.1021/nn4061012.

Alday-Parejo B, Stupp R, Rüegg C. Are integrins still practicable targets for anti-cancer therapy? Cancers. 2019;11(7):978. https://doi.org/10.3390/cancers11070978.

Allegrucci C, Rushton MD, Dixon JE, Sottile V, Shah M, Kumari R, et al. Epigenetic reprogramming of breast cancer cells with oocyte extracts. Mol Cancer. 2011;10(1):1-14. https://doi.org/10.1186/1476-4598-10-7.

Arun AS, Tepper CG, Lam KS. Identification of integrin drug targets for 17 solid tumor types. Oncotarget. 2018;9(53):30146-62. https://doi.org/10.18632/oncotarget.25731.

Baglieri J, Brenner DA, Kisseleva T. The role of fibrosis and liver-associated fibroblasts in the pathogenesis of hepatocelIular carcinoma. Int J Mol Sci. 2019;20(7):1723. https://doi.org/10.3390/ijms20071723.

Bai XM, Zhang W, Liu NB, Jiang H, Lou KX, Peng T, et al. Focal adhesion kinase: important to prostaglandin E2-mediated adhesion, migration and invasion in hepatocellular carcinoma cells. Oncol Rep. 2009;21(1):129-36. https://doi. org/10.3892/or_00000199.

Baiocchini A, Montaldo C, Conigliaro A, Grimaldi A, Correani V, Mura F, et al. Extracellular matrix molecular remodeling in human liver fibrosis evolution. PLoS ONE. 2016;11(3):e0151736. https://doi.org/10.1371/journal.pone.0151736.

Bałaban J, Wierzbicki M, Zielińska M, Szczepaniak J, Sosnowska M, Daniluk K. Effects of graphene oxide nanofilm and chicken embryo muscle extract on muscle progenitor cell differentiation and contraction. Molecules. 2020;25(8):1991. https://doi.org/10.3390/molecules25081991.

Cance WG, Harris JE, lacocca MV, Roche E, Yang X, Chang J, et al. Immunohistochemical analyses of focal adhesion kinase expression in benign and malignant human breast and colon tissues: correlation with preinvasive and invasive phenotypes. Clin Cancer Res. 2000;6(6):2417-23.

Carloni V, Luong TV, Rombouts K. Hepatic stellate cells and extracellular matrix in hepatocellular carcinoma: more complicated than ever. Liver Int. 2014;34(6):834-43. https://doi.org/10.1111/liv.12465.

Chaudhuri PK, Loh KP, Lim CT. Selective accelerated proliferation of malignant breast cancer cells on planar graphene oxide films. ACS Nano. 2016;10(3):3424-34. https://doi.org/10.1021/acsnano.5b07409.

Chehelcheraghi F, Eimani H, Sadraie SH, Torkaman G, Amini A, Shemshadi H. Improved viability of random pattern skin flaps with the use of bone marrow mesenchymal-derived stem cells and chicken embryo extract. Iran J Basic Med Sci. 2015;18(8):764-72.

Chen TC, Lai CH, Chang JL, Chang SW. Mitomycin C retardation of corneal fibroblast migration via sustained dephosphorylation of paxillin at tyrosine 118. Invest Ophth Vis Sci. 2012;53(3):1539-47. https://doi.org/10.1167/iovs.11-9203. 
Cheng B, Wan W, Huang G, LiY, Genin GM, Mofrad MRK, et al. Nanoscale integrin cluster dynamics controls cellular mechanosensing via FAKY397 phosphorylation. Sci Adv. 2020;6(10):eaax1909. https://doi.org/10.1126/sciadv.aax1909.

Cox J, Mann M. MaxQuant enables high peptide identification rates, individualized p.p.b.-range mass accuracies and proteome-wide protein quantification. Nat Biotechnol. 2008;26(12):1367-72. https://doi.org/10.1038/nbt.1511.

Cucina A, Biava PM, D'Anselmi F, Coluccia P, Conti F, di Clemente R, et al. Zebrafish embryo proteins induce apoptosis in human colon cancer cells (Caco2). Apoptosis. 2006;11(9):1617-28. https://doi.org/10.1007/s10495-006-8895-4.

DeBerardinis RJ, Chandel NS. Fundamentals of cancer metabolism. Sci Adv. 2016;2(5):e1600200. https://doi.org/10.1038/ $\operatorname{nrc} 2981$.

Di Crescenzo A, Zara S, Di Nisio C, Ettorre V, Ventrella A, Zavan B, et al. Graphene oxide foils as an osteoinductive stem cell substrate. Acs Appl Bio Mater. 2019;2(4):1643-51. https://doi.org/10.1021/acsabm.9b00041.

Dingemans AM, van den Boogaart V, Vosse BA, van Suylen RJ, Griffioen AW, Thijssen VL. Integrin expression profiling identifies integrin alpha5 and beta1 as prognostic factors in early stage non-small cell lung cancer. Mol Cancer. 2010;9(1):152. https://doi.org/10.1186/1476-4598-9-152.

Essid N, Chambard JC, Elgaaïed AB. Induction of epithelial-mesenchymal transition (EMT) and Gli1 expression in head and neck squamous cell carcinoma (HNSCC) spheroid cultures. Bosn J Basic Med Sci. 2018;18(4):336-46. https://doi. org/10.17305/bjbms.2018.3243.

Fiorillo M, Verre AF, lliut M, Peiris-Pagés M, Ozsvari B, Gandara R, et al. Graphene oxide selectively targets cancer stem cells, across multiple tumor types: implications for non-toxic cancer treatment, via "differentiation-based nano-therapy." Oncotarget. 2015;6(6):3553-62. https://doi.org/10.18632/oncotarget.3348.

Fu Y, Fang Z, Liang Y, Zhu X, Prins P, Li Z, et al. Overexpression of integrin $\beta 1$ inhibits proliferation of hepatocellular carcinoma cell SMMC-7721 through preventing Skp2-dependent degradation of p27 via PI3K pathway. J Cell Biochem. 2007:102(3):704-18. https://doi.org/10.1002/jcb.21323.

Guzman G, Alagiozian-Angelova V, Layden-Almer JE, Layden TJ, Testa G, Benedetti E, et al. p53, Ki-67, and serum alpha feto-protein as predictors of hepatocellular carcinoma recurrence in liver transplant patients. Modern Pathol. 2005;18(11):1498-503. https://doi.org/10.1038/modpathol.3800458.

Haeger A, Krause M, Wolf K, Friedl P. Cell jamming: collective invasion of mesenchymal tumor cells imposed by tissue confinement. Biochim Biophys Acta. 2014;1840(8):2386-95. https://doi.org/10.1016/j.bbagen.2014.03.020.

Hamidi H, Ivaska J. Every step of the way: integrins in cancer progression and metastasis. Nat Rev Cancer. 2018;18(9):53348. https://doi.org/10.1038/s41568-0038-z.

Han T, Kang D, Ji D, Wang X, Zhan W, Fu M, et al. How does cancer cell metabolism affect tumor migration and invasion? Cell Adhes Migr. 2013;7(5):395-403. https://doi.org/10.4161/cam.26345.

Hernandez-Gea V, Toffanin S, Friedman SL, Llovet JM. Role of the microenvironment in the pathogenesis and treatment of hepatocellular carcinoma. Gastroenterology. 2013;144(3):512-27. https://doi.org/10.1053/j.gastro.2013.01.002.

Humphrey JD, Dufresne ER, Schwartz MA. Mechanotransduction and extracellular matrix homeostasis. Nat Rev Mol Cell Biol. 2014;15(12):802-12. https://doi.org/10.1038/nrm3896.

Humphries JD, Byron A, Humphries MJ. Integrin ligands at a glance. J Cell Sci. 2006;119(19):3901-3. https://doi. org/10.1242/jcs.03098.

Iredale JP, Thompson A, Henderson NC. Extracellular matrix degradation in liver fibrosis: biochemistry and regulation. Bba-Mol Basis Dis. 2013;1832(7):876-83. https://doi.org/10.1016/j.bbadis.2012.11.002.

Iwasaki A, Sakai K, Moriya K, Sasaki T, Keene DR, Akhtar R, et al. Molecular mechanism responsible for fibronectin-controlled alterations in matrix stiffness in advanced chronic liver fibrogenesis. J Biol Chem. 2016;291(1):72-88. https:// doi.org/10.1074/jbc.M115.691519.

Jabaily J, Singer M. Neurotrophic and hepatotrophic stimulation of proliferation of embryonic chick muscle cells in vitro: assay and partial characterization of mitogenic activity in chick embryonic organ and tissue extracts. Dev Biol. 1978;64(2):189-202. https://doi.org/10.1016/0012-1606(78)90071-4.

Kasprzak A, Rogacki K, Adamek A, Sterzyńska K, Przybyszewska W, Seraszek-Jaros A, et al. Tissue expression of $\beta$-catenin and $\mathrm{E}$ - and $\mathrm{N}$-cadherins in chronic hepatitis $\mathrm{C}$ and hepatocellular carcinoma. Arch Med Sci. 2017;13(6):1269-80. https://doi.org/10.5114/aoms.2017.65272.

Kiew SF, Kiew LV, Lee HB, Imae T, Chung LY. Assessing biocompatibility of graphene oxide-based nanocarriers: a review. J Control Release. 2016;226:217-28. https://doi.org/10.1016/j.jconrel.2016.02.015.

Kim E, Lisby A, Ma C, Lo N, Ehmer U, Hayer KE, et al. Promotion of growth factor signaling as a critical function of $\beta$-catenin during HCC progression. Nat Commun. 2019;10(1):1909. https://doi.org/10.1038/s41467-019-09780-z.

Klaas M, Kangur T, Viil J, Mäemets-Allas K, Minajeva A, Vadi K, et al. The alterations in the extracellular matrix composition guide the repair of damaged liver tissue. Sci Rep-Uk. 2016;6(1):27398. https://doi.org/10.1038/srep27398.

Koivunen E, Wang B, Ruoslahti E. Isolation of a highly specific ligand for the as/3t integrin from a phage display library. J Cell Biol. 1994;124(3):373-80. https://doi.org/10.1083/jcb.124.3.373.

Kopova I, Bacakova L, Lavrentiev V, Vacik J. Growth and potential damage of human bone-derived cells on fresh and aged fullerene $C_{60}$ films. Int J Mol Sci. 2013;14(5):9182-204. https://doi.org/10.1371/journal.pone.0123680.

Kurantowicz N, Strojny B, Sawosz E, Jaworski S, Kutwin M, Grodzik M, et al. Biodistribution of a high dose of diamond, graphite, and graphene oxide nanoparticles after multiple intraperitoneal injections in rats. Nanoscale Res Lett. 2015;10(1):398. https://doi.org/10.1186/s11671-015-1107-9.

Kurantowicz N, Sawosz E, Halik G, Strojny B, Hotowy A, Grodzik M, et al. Toxicity studies of six types of carbon nanoparticles in a chicken-embryo model. Int J Nanomed. 2017;12:2887-98. https://doi.org/10.2147/IJN.S131960.

Lasocka I, Jastrzębska E, Szulc-Dąbrowska L, Skibniewski M, Pasternak I, Hubalek Kalbacova M, et al. The effects of graphene and mesenchymal stem cells in cutaneous wound healing and their putative action mechanism. Int J Nanomed. 2019;14:2281-99. https://doi.org/10.2147/IJN.S190928.

Lee K, Suzuki H, Aiso S, Matsuoka M. Overexpression of TDP-43 causes partially p53-dependent G2/M arrest and p53-independent cell death in HeLa cells. Neurosci Lett. 2012;506(2):271-6. https://doi.org/10.1016/j.neule t.2011.11.021.

Li TL, Jiang G, Chen Q, Zheng JN. Ki67 is a promising molecular target in the diagnosis of cancer. Mol Med Rep. 2015;11(3):1566-72. https://doi.org/10.3892/mmr.2014.2914. 
Li HH, Qi LN, Ma L, Chen ZS, Xiang BD, Li LQ. Effect of KI-67 positive cellular index on prognosis after hepatectomy in Barcelona Clinic Liver Cancer stage A and B hepatocellular carcinoma with microvascular invasion. Onco Targets Ther. 2018;11:4747-54. https://doi.org/10.2147/OTT.S165244.

Lim SO, Park SJ, Kim W, Park SG, Kim HJ, Kim Yl, et al. Proteome analysis of hepatocellular carcinoma. Biochem Biophys Res Co. 2002;291(4):1031-7. https://doi.org/10.1006/bbrc.2002.6547.

Lin CH, Chung MY, Chen WB, Chien CH. Growth inhibitory effect of the human NIT2 gene and its allelic imbalance in cancers. Febs J. 2007;274(11):2946-56. https://doi.org/10.1111/j.1742-4658.2007.05828.x.

Liu LX, Jiang HC, Liu ZH, Zhou J, Zhang WH, Zhu AL, et al. Integrin gene expression profiles of human hepatocellular carcinoma. World J Gastroenterol. 2002;8(4):631-7. https://doi.org/10.3748/wjg.v8.i4.631.

Liu Y, Wang Z, Wang X. AFM-based study of fullerenol $\left(\mathrm{C}_{60}(\mathrm{OH})_{24}\right)$-induced changes of elasticity in living SMCC-7721 cells. J Mech Behav Biomed. 2015;45:65-74. https://doi.org/10.1016/j.jmbbm.2014.12.011.

Liu Z, Li J, Shan Q, Dai H, Xie H, Zhou L, et al. MCM family in HCC: MCM6 indicates adverse tumor features and poor outcomes and promotes S/G2 cell cycle progression. BMC Cancer. 2018;18(1):200. https://doi.org/10.1186/s1288 5-018-4056-8.

Lu P, Weaver VM, Werb Z. The extracellular matrix: A dynamic niche in cancer progression. J Cell Biol. 2012;196(4):395406. https://doi.org/10.1083/jcb.201102147.

Luo Y, Ren Z, Du B, Xing S, Huang S, LiY, et al. Structure identification of viceninll extracted from Dendrobium officinale and the reversal of TGF- $\beta 1$-induced epithelial-mesenchymal transition in lung adenocarcinoma cells through TGF- $\beta /$ Smad and PI3K/Akt/mTOR signaling pathways. Molecules. 2019;24(1):144. https://doi. org/10.3390/molecules24010144.

Marchesan S, Melchionna M, Prato M. Carbon nanostructures for nanomedicine: opportunities and challenges. Fuller Nanotub Car N. 2014;22(1-3):190-5. https://doi.org/10.1080/1536383X.2013.798726.

Mayoral R, Fernández-Martínez A, Boscá L, Martín-Sanz P. Prostaglandin E 2 promotes migration and adhesion in hepatocellular carcinoma cells. Carcinogenesis. 2005;26(4):753-61. https://doi.org/10.1093/carcin/bgi022.

McCallion C, Burthem J, Rees-Unwin K, Golovanov A, Pluen A. Graphene in therapeutics delivery: problems, solutions and future opportunities. Eur J Pharm Biopharm. 2016;104:235-50. https://doi.org/10.1016/j.ejpb.2016.04.015.

Moreno-Layseca P, Streuli CH. Signalling pathways linking integrins with cell cycle progression. Matrix Biol. 2014;34:144-53. https://doi.org/10.1016/j.matbio.2013.10.011.

Mu X, Sultankulov B, Agarwal R, Mahjoub A, Schott T, Greco N, et al. Chick embryo extract demethylates tumor suppressor genes in osteosarcoma cells. Clin Orthop Relat R. 2014;472(3):865-73. https://doi.org/10.1007/s1199 9-013-3104-6.

Mui KL, Chen CS, Assoian RK. The mechanical regulation of integrin-cadherin crosstalk organizes cells, signaling and forces. J Cell Sci. 2016;129(6):1093-100. https://doi.org/10.1242/jcs.183699.

Naba A, Clauser KR, Whittaker CA, Carr SA, Tanabe KK, Hynes RO. Extracellular matrix signatures of human primary metastatic colon cancers and their metastases to liver. BMC Cancer. 2014;14(1):518. https://doi. org/10.1186/1471-2407-14-518.

Nguyen VH, Meghani NM, Amin HH, Tran TTD, Tran PHL, Park C, et al. Modulation of serum albumin protein corona for exploring cellular behaviors of fattigation-platform nanoparticles. Colloid Surf B. 2018;170:179-86. https://doi. org/10.1016/j.colsurfb.2018.05.060.

PRoteomics IDentifications Database, Hinxton, Cambridgeshire, UK. Identification of chicken embryo muscular and liver proteins. 2020. https://www.ebi.ac.uk/pride/archive/projects/PXD015146. Accessed 28 June 2020.

Ren K, Lu X, Yao N, Chen Y, Yang A, Chen H, et al. Focal adhesion kinase overexpression and its impact on human osteosarcoma. Oncotarget. 2015;6(31):31085-103. https://doi.org/10.18632/oncotarget.5044.

Saneyasu T, Akhtar R, Sakai T. Molecular cues guiding matrix stiffness in liver fibrosis. Biomed Res Int. 2016;2016:2646212. https://doi.org/10.1155/2016/2646212.

Sawosz E, Grodzik M, Hotowy A, Sosnowska M, Urbanowska B, Szczepaniak J, et al. Warsaw University of Life Sciences. The method of multilateral assessment of biocompatibility of materials. Poland patent 423414, Nov 2017.

Schrader J, Gordon-Walker TT, Aucott RL, van Deemter M, Quaas A, Walsh S, et al. Matrix stiffness modulates proliferation, chemotherapeutic response, and dormancy in hepatocellular carcinoma cells. Hepatology. 2011;53(4):1192-205. https://doi.org/10.1002/hep.24108.

Shang N, Wang H, Bank T, Perera A, Joyce C, Kuffel G, et al. Focal adhesion kinase and $\beta$-catenin cooperate to induce hepatocellular carcinoma. Hepatology. 2019;70(5):1631-45. https://doi.org/10.1002/hep.30707.

Sosnowska M, Kutwin M, Jaworski S, Strojny B, Wierzbicki M, Szczepaniak J, et al. Mechano-signalling, induced by fullerene $C_{60}$ nanofilms, arrests the cell cycle in the G2/M phase and decreases proliferation of liver cancer cells. Int J Nanomed. 2019;14:6197. https://doi.org/10.2147/IJN.S206934.

Strojny B, Kurantowicz N, Sawosz E, Grodzik M, Jaworski S, Kutwin M, et al. Long term influence of carbon nanoparticles on health and liver status in rats. PLOS ONE. 2015;10(12):e0144821. https://doi.org/10.1371/journ al.pone.0144821.

Stylianopoulos T, Poh MZ, Insin N, Bawendi MG, Fukumura D, Munn LL, et al. Diffusion of particles in the extracellular matrix: the effect of repulsive electrostatic interactions. Biophys J. 2010;99(5):1342-9. https://doi.org/10.1016/j. bpj.2010.06.016.

Szczepaniak J, Strojny B, Sawosz Chwalibog E, Jaworski S, Jagiello J, Winkowska M, et al. Effects of reduced graphene oxides on apoptosis and cell cycle of glioblastoma multiforme. Int J Mol Sci. 2018;19(12):3939. https://doi. org/10.3390/ijms19123939.

Szmidt M, Sawosz E, Urbańska K, Jaworski S, Kutwin M, Hotowy A, et al. Toxicity of different forms of graphene in a chicken embryo model. Environ Sci Pollut Res Int. 2016;23(19):19940-8. https://doi.org/10.1007/s1135 6-016-7178-z.

Thygesen LG, Ľ̌kkey MM, Micklander E, Engelsen SB. Vibrational microspectroscopy of food. Raman vs. FTIR. Trends Food Sci Tech. 2003;14(1-2):50-7. https://doi.org/10.1016/S0924-2244(02)00243-1.

Tyanova S, Temu T, Carlson A, Sinitcyn P, Mann M, Cox J. Visualization of LC-MS/MS proteomics data in MaxQuant. Proteomics. 2015;15(8):1453-6. https://doi.org/10.1002/pmic.201400449. 
UC San Diego, Health Sciences, California, USA. Cell cycle analysis by DNA content (propidium iodide). 2019. https:// medschool.ucsd.edu/research/moores/shared-resources/flow-cytometry/protocols/Pages/cell-cycle-with-pi.aspx. Accessed 17 June 2019

Vernon RM, Chong PA, Tsang B, Kim TH, Bah A, Farber P, et al. Pi-Pi contacts are an overlooked protein feature relevant to phase separation. Elife. 2018;7:e31486. https://doi.org/10.7554/eLife.31486.

Walker C, Mojares E, del Río HA. Role of extracellular matrix in development and cancer progression. Int J Mol Sci. 2018;19(10):3028. https://doi.org/10.3390/ijms19103028.

Wang K, Ruan J, Song H, Zhang J, Wo Y, Guo S, et al. Biocompatibility of graphene oxide. Nanoscale Res Lett. 2011a;6(8):18. https://doi.org/10.1007/s11671-010-9751-6.

Wang Y, Shenouda S, Baranwal S, Rathinam R, Jain P, Bao L, et al. Integrin subunits alpha5 and alpha6 regulate cell cycle by modulating the chk1 and Rb/E2F pathways to affect breast cancer metastasis. Mol Cancer. 2011b;10(1):1-11. https://doi.org/10.1186/1476-4598-10-84.

Wu S, Zheng Q, Xing X, Dong Y, Wang Y, You Y, et al. Matrix stiffness-upregulated LOXL2 promotes fibronectin production, MMP9 and CXCL12 expression and BMDCs recruitment to assist pre-metastatic niche formation. J Exp Clin Cancer Res. 2018;37(1):99. https://doi.org/10.1186/s13046-018-0761-z.

Xie H, Cao T, Franco-Obregón A, Rosa V. Graphene-induced osteogenic differentiation is mediated by the integrin/FAK axis. Int J Mol Sci. 2019;20(3):574. https://doi.org/10.3390/ijms20030574.

Yin L, Chang C, Xu C. G2/M checkpoint plays a vital role at the early stage of HCC by analysis of key pathways and genes. Oncotarget. 2017;8(44):76305-17. https://doi.org/10.18632/oncotarget.19351.

Yu J, Zhang C, Yu Q, Yu H, Zhang B. ADAR1 p1 10 enhances adhesion of tumor cells to extracellular matrix in hepatocellular carcinoma via up-regulating ITGA2 expression. Med Sci Monit. 2019;25:1469-79. https://doi.org/10.12659/ MSM.911944.

Yue SQ, Yang YL, Dou KF, Li KZ. Expression of PCNA and CD44mRNA in colorectal cancer with venous invasion and its relationship to liver metastasis. World J Gastroenterol. 2003;9(12):2863-5. https://doi.org/10.3748/wjg.v9.112.2863.

Zhang X, Yang M, Shi H, Hu J, Wang Y, Sun Z, et al. Reduced E-cadherin facilitates renal cell carcinoma progression by WNT/ß-catenin signaling activation. Oncotarget. 2017;8(12):19566-76. https://doi.org/10.18632/oncotarget.15361.

Zhu J, Xu M, Gao M, Zhang Z, Xu Y, Xia T, et al. Graphene oxide induced perturbation to plasma membrane and cytoskeletal meshwork sensitize cancer cells to chemotherapeutic agents. ACS Nano. 2017;11(3):2637-51. https://doi. org/10.1021/acsnano.6b07311.

Zielińska-Górska M, Hotowy A, Wierzbicki M, Bałaban J, Sosnowska M, Jaworski S, et al. Graphene oxide nanofilm and the addition of L-glutamine can promote development of embryonic muscle cells. J Nanobiotechnol. 2020;18(1):1-17. https://doi.org/10.1186/s12951-020-00636-z.

\section{Publisher's Note}

Springer Nature remains neutral with regard to jurisdictional claims in published maps and institutional affiliations.

Ready to submit your research? Choose BMC and benefit from:

- fast, convenient online submission

- thorough peer review by experienced researchers in your field

- rapid publication on acceptance

- support for research data, including large and complex data types

- gold Open Access which fosters wider collaboration and increased citations

- maximum visibility for your research: over 100M website views per year

At BMC, research is always in progress.

Learn more biomedcentral.com/submissions 